Supporting Information for:

\title{
Synthesis of ADP-Ribosylated Histones Reveals Site-Specific Impacts on Chromatin Structure and Function
}

\author{
Nir Hananya, Sara K. Daley, John D. Bagert and Tom W. Muir* \\ Department of Chemistry, Princeton University, Princeton, New Jersey 08544, United States
}

*Correspondence: muir@princeton.edu

- Materials and Methods

S2-S8

- Supplementary Figures .............................................................. S9-S13

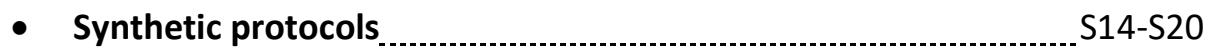

- NMR Spectra

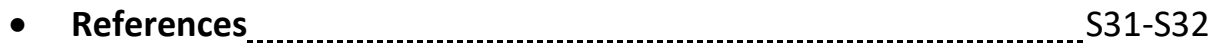




\section{General laboratory materials and methods}

Commonly used chemical reagents and solvents, including dimethylformamide (DMF), dichloromethane (DCM), and triisopropylsilane (TIPS), were purchased from Sigma-Aldrich and used without further purification. Trifluoroacetic acid (TFA) was purchased from Halocarbon (North Augusta, SC). Analytical reversed-phase HPLC (RP-HPLC) was performed on an Agilent 1260 series instrument employing a Vydac C18 column $(5 \mu \mathrm{m}, 150 \mathrm{~mm} \times 4 \mathrm{~mm})$ at a flow rate of $1 \mathrm{~mL} / \mathrm{min}$. Semi-preparative scale purifications were performed on an Agilent 1260 series instrument employing a Vydac C18 semipreparative column (12 $\mu \mathrm{m}, 10$ $\mathrm{mm} \times 250 \mathrm{~mm}$ ) at a flow rate of $4 \mathrm{~mL} / \mathrm{min}$. Preparative RP-HPLC was performed on a Waters Prep LC system comprised of a Waters 2545 Binary Gradient Module and a Waters 2489 UV detector. Purifications were carried out on a C18 Vydac 218TP1022 column (10 $\mathrm{M} ; 22 \mathrm{~mm} \times 250 \mathrm{~mm})$ at a flow rate of $20 \mathrm{~mL} / \mathrm{min}$. For all RP-HPLC purifications and analyses, 0.1\% TFA in water (HPLC solvent A) and 90\% acetonitrile, 0.1\% TFA in water (HPLC solvent B) were used as the mobile phases. Electrospray ionization mass spectrometry (ESI-MS) analysis of peptides and proteins was conducted on a micrOTOF-Q II ESI-Qq-TOF mass spectrometer (Bruker Daltonics).

\section{Synthesis of ADP-ribosylated peptide $\alpha$-thioesters}

The following peptide hydrazides were synthesized by Fmoc-based solid-phase peptide synthesis:

(i) H2B 1-16 $_{16}$ ADPr: PEPAKS(ADPr)APAPKKGSKK-NHNH 2 ; (ii) H3 ${ }_{1-14} \mathrm{~S} 10 A D P r$ : ARTKQTARKS(ADPr)TGGK-NHNH ${ }_{2}$, where $S(A D P r)$ refers to $O$-linked ADP ribosylated serine. Fmoc-protected amino acids were purchased from Matrix Innovations (Quebec, Canada). Peptides $(0.05 \mathrm{mmol}$ ) were synthesized manually on ChemMatrix Trityl$\mathrm{OH}$ resin, preloaded with a hydrazine linker. Each cycle included: i) Fmoc deprotection with $20 \%$ piperidine in DMF (15 min) and ii) coupling of 5 eq. of each amino acid with 5 eq. of (7-Azabenzotriazol-1yloxy)tripyrrolidinophosphonium hexafluorophosphate (PyAOP) and 10 eq. diisopropylethylamine (DIPEA) for $20 \mathrm{~min}$. The coupling step was repeated twice, except for the more precious amino acids - compound $\mathbf{1}$ and Fmoc-Arg(Mis)-OH (see below).

Phosphoribosylated serine derivative 1 was incorporated at position 6 for the H2B peptide and position 10 for the $\mathrm{H} 3$ peptide. Boc-Pro-OH (for H2B) or Boc-Ala-OH (for H3) were used for the final coupling reaction at the $\mathrm{N}$-termini of the peptides. To minimize the time required for the TFA-mediated side-chain deprotection, we used several amino acids with increased acid lability of the side chain protecting group: Serine - Fmoc-Ser(Trt)-OH; Threonine - Fmoc-Thr(Trt)-OH; Arginine - Fmoc-Arg(Mis)-OH, ${ }^{1}$ which was synthesized according to the procedure reported by Isidro et al. (ref. 1), starting from 1,2-dimethyl-1H-indole3-sulfonyl chloride (Enamine \#EN300-99106). For the coupling of Fmoc-Arg(Mis)-OH, and for the coupling of compound 1, we used 2 eq of the amino acid with 2 eq of PYAOP and 4 eq of DIPEA for $1 \mathrm{~h}$.

Subsequent to peptide chain synthesis, the following steps were performed on-resin:

1. Phosphate allyl deprotection: The resin was rinsed 3 times with DCM, followed by incubation with $\mathrm{Pd}\left(\mathrm{PPh}_{3}\right)_{4}(1 \mathrm{eq})$ and 1,3-dimethylbarbituric acid (15 eq) in $3 \mathrm{~mL}$ of DCM for $1 \mathrm{~h}$. This step was repeated twice. Test cleavage and LC-MS showed full deprotection of the diallyl phosphate. 
2. Pyrophosphate bond formation: The resin was rinsed 3 times with dry MeCN, followed by the addition of adenosine phosphoramidite 2 (3 eq) in $2 \mathrm{~mL}$ of dry MeCN. $2 \mathrm{~mL}$ of ETT activator (0.25 M in MeCN, Glen Research \#30-3140-45) were added, and the resin was agitated by nitrogen bubbling for $10 \mathrm{~min}$. This step was repeated twice.

3. Phosphite oxidation: The resin was rinsed 3 times with dry MeCN, followed by the addition of 10 $\mathrm{mL}$ of $0.1 \mathrm{M}$ CSO oxidant in acetonitrile (Glen Research \#40-4631-52). Incubation time $-2 \times 5 \mathrm{~min}$.

4. 2-cyanoethyl deprotection: The resin was incubated with 15\% DBU in dry DMF for 5 min.

Finally, peptide cleavage and side-chain deprotection were carried out with a cleavage cocktail (96\% TFA, 4\% TIPS) for $10 \mathrm{~min}$. Cold diethyl ether was added to precipitate the peptide, which was collected by centrifugation, resuspended in ether, and collected again. The peptide was dissolved in HPLC solvent A (0.1\% TFA in water), purified by preparative RP-HPLC and lyophilized.

Conversion of the peptide hydrazides to peptide $\alpha$-thioesters:

Peptide hydrazides were converted to peptide thioesters according to the protocol developed by Flood et al., ${ }^{2}$ with minor modifications. The peptides $(1 \mathrm{mM})$ were dissolved in a suspension of $100 \mathrm{mM}$ MPAA in $6 \mathrm{M}$ Gdn$\mathrm{HCl}$. 10x stock solution of acetylacetone in water was added (final concentration $2.5 \mathrm{mM}$ ), pH was adjusted carefully to 3 with $1 \mathrm{M} \mathrm{NaOH}$, and the reaction was mixed overnight at RT. The solution was diluted with HPLC solvent A, filtered, and purified by preparative RP-HPLC. Pure fractions were pooled and lyophilized, providing

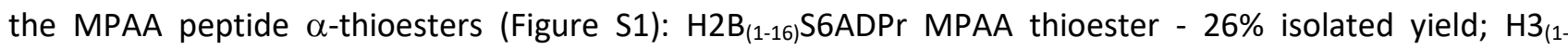
${ }_{14)}$ S10ADPr MPAA thioester - $12 \%$ isolated yield.

\section{Expression and purification of histone proteins}

Wild-type histone proteins: Histone proteins were expressed and purified according to a previous protocol. ${ }^{3}$ Histone expression plasmids were transformed into BL21(DE3) cells and grown at $37^{\circ} \mathrm{C}$ to $\mathrm{OD}_{600}=0.6$. Protein expression was induced with $0.5 \mathrm{mM}$ IPTG for 3 hours. Cells were collected and lysed by sonication in a lysis buffer containing $50 \mathrm{mM}$ Tris- $\mathrm{HCl}, \mathrm{pH}$ 7.5, $150 \mathrm{mM} \mathrm{NaCl}, 5 \mathrm{mM} \beta$-mercaptoethanol, and $1 \mathrm{mM}$ PMSF. The insoluble fraction was isolated by centrifugation at $39000 \mathrm{~g}$ for 20 minutes. Histone proteins were extracted from the inclusion bodies by nutation with an extraction buffer containing $50 \mathrm{mM}$ Tris- $\mathrm{HCl} \mathrm{pH} \mathrm{7.5,} 6 \mathrm{M}$ Gdn$\mathrm{HCl}$, and $5 \mathrm{mM} \beta$-mercaptoethanol for $1 \mathrm{~h}$ at RT. Following centrifugation at $390000 \mathrm{~g}$ for $30 \mathrm{~min}$, the supernatant was acidified with TFA to $\mathrm{pH} 2$. The solution was clarified using ultracentrifugation (50000 rpm for $30 \mathrm{~min}$ ) and filtered with a $0.45 \mu \mathrm{M}$ syringe filter. The resulting clear solution was injected onto a preparative RP-HPLC, and pure histone fractions were pooled, lyophilized, and stored at $-80{ }^{\circ} \mathrm{C}$.

Truncated $\mathrm{H}_{2} \mathrm{~B}_{17-125} \mathrm{~A} 17 \mathrm{C}$ : The protein was expressed and purified as described in Chiang et al., ${ }^{4}$ with modifications. An expression plasmid containing the $\mathrm{H}_{2} \mathrm{~B}_{17-125} \mathrm{~A} 17 \mathrm{C}$ sequence (preceded by a methionine) was transformed into BL21(DE3) cells. Expression and purification were carried out as described for the wild-type histone proteins. During expression, the initiator methionine was excised by bacterial aminopeptidase, exposing the $\mathrm{N}$-terminal cysteine. Consequently, the purified protein was obtained as a thiazolidine adduct of the $\mathrm{N}$-terminal cysteine with carbonyl-containing metabolites. To reverse the thiazolidine formation and 
generate free $\mathrm{N}$-terminal cysteine, the lyophilized protein was dissolved in unbuffered methoxylamine (400 $\mathrm{mM})+20 \mathrm{mM}$ TCEP. $\mathrm{pH}$ was adjusted to 3 , and the reaction was nutated at $37^{\circ} \mathrm{C}$ for $60 \mathrm{~min}$, upon which LCMS showed full conversion to the desired N-terminal cysteine. The solution was injected directly onto RPHPLC, and pure fractions were pooled, lyophilized, and stored at $-80^{\circ} \mathrm{C}$.

Truncated $\mathrm{H} 3_{15-135} \mathrm{~A} 15 \mathrm{C}$ was expressed and purified as reported by Liszczak et al. ${ }^{5}$

\section{Native chemical ligation and desulfurization of ADP-ribosylated histones}

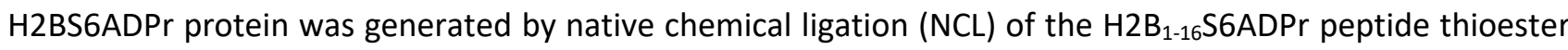
with the recombinant $\mathrm{H}_{2} \mathrm{~B}_{17-125} \mathrm{~A} 17 \mathrm{C}$. $\mathrm{H} 3 \mathrm{~S} 10 \mathrm{ADPr}$ protein was generated $\mathrm{NCL}$ of the $\mathrm{H} 3_{1-14} \mathrm{~S} 10 \mathrm{ADPr}$ peptide thioester with the recombinant $\mathrm{H} 3_{15-135} \mathrm{~A} 15 \mathrm{C}$. Reaction conditions: $1 \mathrm{mM}$ recombinant fragment with 2 eq of the corresponding peptide $\alpha$-thioester, mixed at RT in ligation buffer $(6 \mathrm{M} \mathrm{Gdn-HCl,} 100 \mathrm{mM}$ sodium phosphate buffer, $\mathrm{pH} 7.0,50 \mathrm{mM}$ TCEP, $2 \% \mathrm{v} / \mathrm{v}$ trifluoroethanethiol). There was no significant change in the RP-HPLC retention time between the $\mathrm{N}$-terminal cysteine fragment and the ligation product. Therefore, reaction monitoring was carried out by analytical RP-HPLC, collecting the peak that corresponds to both the $\mathrm{N}$-terminal cysteine reactant and the ligation product, and analyzing the peak by ESI-QTOF MS. For both histone proteins, ligation proceeded smoothly and reached completion after $2 \mathrm{~h}$. Subsequently, the reaction mixture was diluted with HPLC solvent $A$, acidified to $\mathrm{pH} 2$, and purified by semipreparative RP-HPLC. Pure fractions were pooled and lyophilized (see Figure S2).

The ligation products were converted to the native histone proteins through free radical-mediated desulfurization. Each protein was dissolved in ligation buffer $(1 \mathrm{mM})$, and an equal volume of $500 \mathrm{mM}$ TCEP in $6 \mathrm{M} \mathrm{Gdn}-\mathrm{HCl}(\mathrm{pH} 6.5)$ was added. To this solution, reduced glutathione ( $40 \mathrm{mM})$ and VA-044 radical initiator (20 mM) were added as solids, $\mathrm{pH}$ was adjusted to 6.4 , and the reaction was incubated at $37^{\circ} \mathrm{C}$ for 8 hours, upon which analysis by ESI-QTOF (as described above) showed full desulfurization of the cysteine residue. Subsequently, the reaction was diluted with HPLC solvent $\mathrm{A}$, acidified to $\mathrm{pH} 2$, and purified by semipreparative RP-HPLC. Pure fractions were pooled, lyophilized, and stored at $-80^{\circ} \mathrm{C}$.

\section{Histone octamer refolding}

Histone octamer refolding was performed as reported previously, ${ }^{6}$ by mixing H2A, H2B (unmodified or ADPribosylated), $\mathrm{H} 3$ (unmodified or ADP-ribosylated) and $\mathrm{H} 4$ in an unfolding buffer ( $6 \mathrm{M} \mathrm{Gdn}-\mathrm{HCl}, 20 \mathrm{mM} \mathrm{Tris}-\mathrm{HCl}$, $\mathrm{pH} 7.5,0.5 \mathrm{mM}$ EDTA, $5 \mathrm{mM}$ DTT), followed by dialysis into a refolding buffer ( $20 \mathrm{mM}$ Tris- $\mathrm{HCl}, \mathrm{pH} 7.5,2 \mathrm{M}$ $\mathrm{NaCl}, 0.5 \mathrm{mM}$ EDTA, $1 \mathrm{mM}$ DTT) and purification through size-exclusion chromatography. Pure octamer fractions were pooled, glycerol was added to $10 \% \mathrm{v} / \mathrm{v}$, and the octamer solution was aliquoted, flash-frozen, and stored at $-80^{\circ} \mathrm{C}$. 


\section{Reconstitution of mononucleosomes}

The 'Widom 601' DNA sequence ${ }^{7}$ with 15 base-pair overhangs was used for nucleosome assembly. Histone octamers (150 pmol) were combined with 1 molar equivalent of the 601 DNA (the precise optimal octamer/DNA ratios were determined experimentally) in $75 \mu \mathrm{L}$ buffer $(2 \mathrm{M} \mathrm{NaCl}, 10 \mathrm{mM}$ Tris- $\mathrm{HCl}, 0.1 \mathrm{mM}$ EDTA, $1 \mathrm{mM} \mathrm{DTT}$, pH 7.5 at $4{ }^{\circ} \mathrm{C}$ ). The mixtures were placed in Slide-A-Lyzer MINI dialysis devices (3.5 kDa MW cutoff, Thermo Fisher Scientific) and dialyzed at $4{ }^{\circ} \mathrm{C}$ against $200 \mathrm{~mL}$ nucleosome assembly start buffer (10 $\mathrm{mM}$ Tris- $\mathrm{HCl}, 1.4 \mathrm{M} \mathrm{KCl}, 0.1 \mathrm{mM}$ EDTA, $1 \mathrm{mM} \mathrm{DTT}$, pH 7.5 at $4{ }^{\circ} \mathrm{C}$ ) for $1 \mathrm{~h}$ at $4{ }^{\circ} \mathrm{C}$. Subsequently, $330 \mathrm{~mL}$ of nucleosome assembly end buffer $\left(10 \mathrm{mM}\right.$ Tris- $\mathrm{HCl}, 10 \mathrm{mM} \mathrm{KCl}, 0.1 \mathrm{mM}$ EDTA, $1 \mathrm{mM} \mathrm{DTT}$, pH 7.5 at $\left.4{ }^{\circ} \mathrm{C}\right)$ were added at a rate of $1 \mathrm{~mL} / \mathrm{min}$ using a peristaltic pump, followed by two dialysis steps against nucleosome assembly end buffer $(2 \times 2 \mathrm{~h}$ ). The dialyzed mixture was transferred to a microcentrifuge tube, and any precipitate was removed by centrifugation at $17000 \mathrm{~g}$. Nucleosome concentration was quantified by UV spectroscopy at $260 \mathrm{~nm}$. The quality of individual nucleosomes was assessed by native PAGE (5\% acrylamide gel, 120 V, $60 \mathrm{~min}$ ), followed by SYBR Gold staining (Figure S3).

\section{ARH3 treatment of ADP-ribosylated MNs and nucleosome arrays}

The ADP-ribose glycohydrolase ARH3 was expressed in E. Coli as reported by Liszczak et al. ${ }^{5}$ To test the ADPribosylated MNs (as in Figure 2e), MNs (100 nM) were treated with ARH3 $(1 \mu \mathrm{M})$ in $20 \mathrm{mM}$ Tris-HCl, $\mathrm{pH} 7.5$, $50 \mathrm{mM} \mathrm{NaCl}, 2 \mathrm{mM} \mathrm{MgCl}, 0.1 \mathrm{mg} / \mathrm{mL}$ BSA for $30 \mathrm{~min}$ at RT, and were analyzed by native PAGE. In the case of ADP-ribosylated nucleosome arrays (as in Figure 2f), ARH3 $(1 \mu \mathrm{M})$ was added directly to the BstXI digestion reaction (see below).

\section{Reconstitution of 12-mer nucleosome arrays}

As a template for the 12-mer nucleosome arrays, we used a 2184 bp DNA, which harbors 12 copies of the Widom 601 sequence, separated by a 35-bp linker. The DNA template was cloned into a WM530 vector as described by Gibson et al. ('pWM_12x601_35bpLinker'), ${ }^{8}$ and the plasmid was purified from DH5 $\alpha$ cells according to a previously published procedure. ${ }^{6}$ The $12 \times 601$ was excised from the plasmid using treatment with the EcoRV restriction enzyme $(500 \mathrm{U} / \mathrm{mL}$ of EcoRV, plasmid concentration $1 \mathrm{mg} / \mathrm{mL})$ at $37^{\circ} \mathrm{C}$ for 24 hours. Excised 12x601 was purified from plasmid backbone fragments using 4.5\% PEG-6000 precipitation. Following purification, proteins and PEG were removed by phenol-chloroform extraction and ethanol precipitation. The remaining 12x601 DNA pellet was dissolved in $10 \mathrm{mM}$ Tris- $\mathrm{HCl} \mathrm{pH} \mathrm{8.0,0.1} \mathrm{mM} \mathrm{EDTA} \mathrm{buffer,} \mathrm{aliquoted,} \mathrm{and}$ stored at $-20^{\circ} \mathrm{C}$.

12-mer nucleosome arrays were assembled similarly to mononucleosomes using 1 molar equivalent of octamer complex per 601 nucleosome-positioning site (the precise optimal octamer/DNA ratio was determined experimentally). Following assembly, as an additional final purification step, arrays were precipitated by an equal volume of $8 \mathrm{mM} \mathrm{MgCl}_{2}$ in $\mathrm{H}_{2} \mathrm{O}$, isolated by centrifugation at $17000 \mathrm{~g}$, and re-dissolved in the desired working buffer $(10 \mathrm{mM}$ Tris- $\mathrm{HCl} \mathrm{pH} \mathrm{7.5,} 2.5 \mathrm{mM} \mathrm{NaCl}, 0.1 \mathrm{mM}$ EDTA for sedimentation velocity 
experiments; $10 \mathrm{mM}$ Tris- $\mathrm{HCl} \mathrm{pH}$ 7.5, $10 \mathrm{mM} \mathrm{KCl}, 0.1 \mathrm{mM}$ EDTA for $\mathrm{Mg}^{2+}$-mediated self-association experiments, see below). Arrays were analyzed by native agarose-acrylamide composite gel ( $1 \%$ agarose, $2 \%$ acrylamide). Additionally, arrays were digested to mononucleosomes by treatment with BstXI restriction enzyme (NEB) in $20 \mathrm{mM}$ Tris- $\mathrm{HCl}, \mathrm{pH} 7.5,50 \mathrm{mM} \mathrm{NaCl}, 2 \mathrm{mM} \mathrm{MgCl}, 0.1 \mathrm{mg} / \mathrm{mL} \mathrm{BSA}\left(1 \mathrm{~h}\right.$ at $37^{\circ} \mathrm{C}$ ). The resulting solution was analyzed by native PAGE on $5 \%$ polyacrylamide gel and stained with SYBR Gold. Note, digestion of fully saturated arrays should give rise to a major band corresponding to mononucleosome in the range of $500-600 \mathrm{bp}$.

For the control experiment described in Figure S5, in which the ADPr mark was removed from the nucleosome arrays prior to sedimentation velocity analysis, we treated the arrays with ARH3. This step was carried out after the arrays assembly by salt gradient dialysis and before the arrays precipitation with $\mathrm{Mg}^{2+} .1$ $\mathrm{mM} \mathrm{MgCl} 2$ was added to a solution of the arrays in assembly end buffer $(10 \mathrm{mM}$ Tris- $\mathrm{HCl}, 10 \mathrm{mM} \mathrm{KCl}, 0.1 \mathrm{mM}$ EDTA, $1 \mathrm{mM} \mathrm{DTT}$, pH 7.5 at $\left.4{ }^{\circ} \mathrm{C}\right)$, followed by the addition of ARH3 $(1 \mu \mathrm{M})$. Upon incubation at RT for $30 \mathrm{~min}$, the arrays were precipitated by an equal volume of $7 \mathrm{mM} \mathrm{MgCl}_{2}$ in $\mathrm{H}_{2} \mathrm{O}$, isolated by centrifugation, and redissolved for sedimentation velocity analysis as described above.

\section{Mononucleosome thermal stability assays}

Nucleosome stability was measured using the SYPRO Orange (Sigma-Aldrich) thermal stability assay, ${ }^{9}$ as described recently. ${ }^{10}$ SYPRO Orange was supplied as a 5,000x concentrated solution from the manufacturer and was used at a final concentration of $5 \times$ in the assay. Assays were performed in a reaction volume of $10 \mu \mathrm{L}$ in $10 \mathrm{mM}$ TEK (10 mM Tris-HCl, pH 7.5, $10 \mathrm{mM} \mathrm{KCl,} 0.1 \mathrm{mM}$ EDTA) with an $\mathrm{MN}$ concentration of 0.5-1 $\mu \mathrm{M}$. Samples were analyzed in four technical replicates in 384-well plates in a ViiA 7 Real-Time PCR System (Applied Biosystems). $T_{\text {half, }}$ the temperature at which half of the $\mathrm{H} 2 \mathrm{~A} / \mathrm{H} 2 \mathrm{~B}$ dimers are melted off the nucleosome, was calculated by fitting fluorescence measurements at temperatures between 45 and $83^{\circ} \mathrm{C}$ to a standard sigmoid function and calculating the inflection point. Fits were performed in Python v.2.7.10 using the optimize.curve_fit function in the SciPy library (v.0.15.1).

\section{Sedimentation Velocity Analysis}

Measurements were performed at $20^{\circ} \mathrm{C}$ in $10 \mathrm{mM}$ Tris- $\mathrm{HCl}, \mathrm{pH} \mathrm{7.5,} 0.1 \mathrm{mM}$ EDTA, $2.5 \mathrm{mM} \mathrm{NaCl}$, in the presence or absence of $1 \mathrm{mM} \mathrm{MgCl}$. All samples $\left(400 \mu \mathrm{L}\right.$ ) had an $\mathrm{A}_{260}$ of $\sim 0.4$. Samples were equilibrated under vacuum for $2 \mathrm{~h}$ at $20^{\circ} \mathrm{C}$ in an analytical ultracentrifuge (Beckman Optima AUC) before starting the centrifugation at 12,000 rpm in an An-50 Ti rotor (8-place). Absorbance was measured at $260 \mathrm{~nm}$ in $120 \mathrm{~s}$ increments for at least 300 scans.

Analysis was performed using sedfit. ${ }^{11}$ Boundary fractions were calculated by van Holde-Weischet analysis according to the sedfit protocols. ${ }^{12} \mathrm{~S}_{20, w}$ values were calculated by adjusting for a partial specific volume of $0.622 \mathrm{~mL} / \mathrm{gr}$ for chromatin and buffer viscosity. ${ }^{13}$ Mean $\mathrm{S}_{20, \mathrm{w}}$ values were obtained by averaging over the dominant homogenous fraction. 


\section{$\mathrm{Mg}^{2+}$-mediated array self-association}

$\mathrm{Mg}^{2+}$-mediated array self-association experiments were performed as described by Debelouchina et al. ${ }^{14}$ The assays were performed at $0.25 \mu \mathrm{M} 601$ sites in $10 \mathrm{mM}$ Tris- $\mathrm{HCl}, \mathrm{pH}$ 7.5, $10 \mathrm{mM} \mathrm{KCl}, 0.1 \mathrm{mM}$ EDTA. Briefly, 5 $\mu \mathrm{L}$ of $2 \times$ array sample ( $0.5 \mu \mathrm{M}$ of 601 sites) were incubated with $5 \mu \mathrm{L}$ of $2 \times \mathrm{MgCl}_{2}$ solution in $\mathrm{H}_{2} \mathrm{O}$ for 10 min at RT. Samples were centrifuged at $17,000 \times \mathrm{g}$ for $10 \mathrm{~min}$ at $15{ }^{\circ} \mathrm{C}$, and the supernatants were transferred to a fresh tube. $4 \mu \mathrm{L}$ of the supernatant were added to a black, flat-bottom 96-well plate, to which $160 \mu \mathrm{L}$ of SYBR Gold (1:10000) in $\mathrm{H}_{2} \mathrm{O}$ were added. The dye fluorescence was recorded by a plate reader (SpectraMax M3, Molecular Devices) for each $\mathrm{Mg}^{2+}$ concentration, and the percentage of the nucleosome array in the supernatant was inferred accordingly. Two technical replicates were performed for each precipitation experiment, and the data for 3-6 independent precipitation experiments were averaged.

\section{Lysine methyltransferase enzymes - expression and purification}

G9a - The recombinant G9a used in this study was generated in Sf9 cells using the baculovirus system. MSCVhygro-flag-G9a was a gift from Kai Ge (Addgene plasmid \#41721) and used to subclone the full-length flag-G9a into a pFastBac vector (Invitrogen). Plasmids were used to generate bacmids in DH10Bac cells according to the manufacturer's protocol (Invitrogen). Bacmids (1 $\mathrm{gg})$ were transfected into Sf9 cells over $72 \mathrm{hrs}$ at $27^{\circ} \mathrm{C}$ to generate the baculovirus P1 stock. The P1 baculovirus was used to infect Sf9 cells $\left(2 \times 10^{6}\right.$ cells $/ \mathrm{mL}, 25 \mathrm{~mL}$ ) grown in suspension in Sf-900III serum-free media (Thermo Fischer) until Sf9 cell viability was below $40 \%$ viable. The resulting P2 viral stock was amplified through infection into Sf9 cells $\left(2 \times 10^{6}\right.$ cells $/ \mathrm{mL}$, $50 \mathrm{~mL}$ ) to produce the P3 viral stock. After $2 \mathrm{~d}$ infection with P3 (1:100 dilution in $500 \mathrm{~mL}$ of cells at $2 \times 10^{6}$ cells $/ \mathrm{mL}$ ), cells were harvested by centrifugation and stored at $-80^{\circ} \mathrm{C}$. Flag-tagged G9a was purified from insect cell pellets according to a previously established protocol with a few amendments. ${ }^{15}$ Cells were thawed and lysed by sonication ( $50 \%$ amplitude, 5 min, pulsed) in buffer $\mathrm{H}(50 \mathrm{mM}$ Tris- $\mathrm{HCl}, \mathrm{pH}$ 8, $500 \mathrm{mM} \mathrm{NaCl}, 5 \mathrm{mM} \beta$ mercaptoethanol, and $2 \mathrm{mM} \mathrm{PMSF}$ and Roche PI tablet). After sonication, DNAse (10 $\mu \mathrm{g} / \mathrm{mL})$ was added, and cells were incubated on ice for $30 \mathrm{~min}$. The lysate was clarified by centrifugation $\left(39,000 \mathrm{~g}\right.$ for $30 \mathrm{~min}$ at $\left.4{ }^{\circ} \mathrm{C}\right)$ followed by an additional ultra-centrifugation step $\left(50,000 \mathrm{~g}\right.$ for $30 \mathrm{~min}$ at $\left.4{ }^{\circ} \mathrm{C}\right)$. The soluble lysate was incubated with anti-FLAG M2 affinity gel (100 $\mu \mathrm{L}$ resin per $100 \mathrm{~mL}$ cell culture) for $3 \mathrm{~h}$ at $4{ }^{\circ} \mathrm{C}$ with end-overend rotation. The resin was collected by centrifugation and washed 3 times with 10 column volumes of wash buffer ( $50 \mathrm{mM}$ Tris- $\mathrm{HCl}, \mathrm{pH} 8,1 \mathrm{mM} \mathrm{NaCl}, 5 \mathrm{mM} \beta$-mercaptoethanol, and 0.01\% NP-40) and twice with 10 column volumes of buffer $\mathrm{H}$. Bound protein was eluted in buffer $\mathrm{H}$ supplemented with $0.25 \mathrm{mg} / \mathrm{mL}$ FLAG peptide $\left(x 3,20 \mathrm{~min}\right.$ at $\left.4{ }^{\circ} \mathrm{C}\right)$. Eluted fractions were concentrated using Vivaspin centrifugal concentrators (MWCO 30,000 kDa) and analyzed by denaturing gel electrophoresis ( $8 \%$ acrylamide, $1 x$ Tris-glycine, $180 \mathrm{~V}$ for $60 \mathrm{~min})$. Concentrated protein was aliquoted and stored at $-80^{\circ} \mathrm{C}$.

MLL1 - MLL1 complex was assembled from 5 subunits: (1) residues 3745-3969 of the human MLL1 protein; (2) WDR5; (3) RBBP5; (4) DPY30; (5) residues 95- 628 of ASH2L. The proteins were expressed in E. Coli and purified as reported previously. ${ }^{16}$ 
$\underline{\text { PRC2 }}$ - PRC2 core complex, which consists of Flag-tagged EZH2, His-tagged EED, RBBP4, and SUZ12, was prepared in Sf9 cells as reported previously. ${ }^{3}$

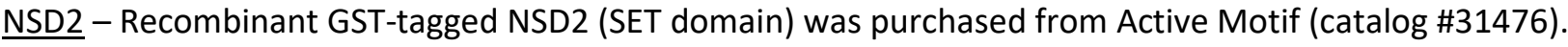

\section{Histone methyltransferase (HMT) assays}

Radioactivity-based HMT assays with G9a:

Reaction buffer: $50 \mathrm{mM}$ HEPES, pH 8.5 at RT, 1 mM MgCl $2,5 \mathrm{mM} \mathrm{DTT}, 1 \mu \mathrm{M}\left[{ }^{3} \mathrm{H}\right] \mathrm{SAM}$ (Perkin Elmer NET155V), $50 \mathrm{nM}$ G9a. To $5 \mu \mathrm{L}$ of the various MNs (wt, H2BADPr, H3ADPr, dual ADPr) at $1 \mu \mathrm{M}$ concentration in TEK buffer (10 mM Tris- $\mathrm{HCl}, \mathrm{pH} 7.5$ at $4{ }^{\circ} \mathrm{C}, 10 \mathrm{mM} \mathrm{KCl}, 0.1 \mathrm{mM}$ EDTA) were added $5 \mu \mathrm{L}$ of $2 x$ reaction buffer. The reactions were incubated at $30^{\circ} \mathrm{C}$ for $30 \mathrm{~min}$ and then quenched by adding $4 \mathrm{X}$ SDS loading dye. Reaction mixtures were loaded on a $12 \%$ TBE gel ( $160 \mathrm{~V}, 50 \mathrm{~min})$. The gel was stained with coomassie for $30 \mathrm{~min}$, and then was destained for $30 \mathrm{~min}$ and treated with Amplify solution (Cytiva, NAMP100) for $30 \mathrm{~min}$. Coomassie signal was read using Odyssey imager (700 channel) and was used as a nucleosome loading control.

Next, autoradiography was carried out to measure $\mathrm{H} 3 \mathrm{~K} 9$ methylation: the gel was dried at $65^{\circ} \mathrm{C}$ for 2 $h$ on the gel dryer and left to dry under vacuum at RT overnight. Subsequently, the gel was exposed to a film (Carestream BioMax XAR film, Sigma) under dark conditions at $-80^{\circ} \mathrm{C}$ for $28 \mathrm{~h}$. The film was developed and scanned using the ImageQuant ${ }^{T M}$ LAS 4000 imager. Autoradiography intensities were quantified using GelAnalyzer 19.1 (www.gelanalyzer.com).

Cold HMT assays with MLL1, PRC2 or NSD2:

Reaction buffer: $50 \mathrm{mM}$ Tris- $\mathrm{HCl}, \mathrm{pH} 8.5$ at RT, $50 \mathrm{mM} \mathrm{KCl}, 5 \mathrm{mM}$ DTT, $2 \mathrm{mM} \mathrm{MgCl}$, and 0.1\% Tween-20, 100 $\mu \mathrm{M}$ SAM. The various lysine methyltransferases (KMTs) were included at $250 \mathrm{nM}$ concentration. For PRC2, the reaction also contained $20 \mu \mathrm{M}$ of the PRC2 stimulating peptide $\left(\mathrm{H}_{21-37}, \mathrm{~K} 27 \mathrm{me} 3\right) .{ }^{17}$ To $5 \mu \mathrm{L}$ of the various MNs (wt, H2BADPr, H3ADPr, dual ADPr) at $1 \mu \mathrm{M}$ concentration in TEK buffer $\left(10 \mathrm{mM}\right.$ Tris- $\mathrm{HCl}, \mathrm{pH} 7.5$ at $4^{\circ} \mathrm{C}, 10 \mathrm{mM}$ $\mathrm{KCl}, 0.1 \mathrm{mM}$ EDTA) were added $5 \mu \mathrm{L}$ of $2 \mathrm{x}$ reaction buffer. The reactions were incubated at $25^{\circ} \mathrm{C}$ for $90 \mathrm{~min}$ and samples were taken at specific time points as shown in Figure S7. The reaction was quenched by adding 4X SDS loading dye. Methylation level was analyzed by western blot with the following antibodies: anti H3K4me3 (CST \#9751S) for MLL1-mediated methylation; anti H3K27me3 (Active motif \#39155) for PRC2mediated methylation; anti H3K36me2 (CST \#2901S) for NSD2-mediated methylation. To detect H4 as a loading control, we used anti-H4 antibody (abcam \#ab31830). The experiments were repeated three times with similar results. 


\section{Supplementary Figures}

a
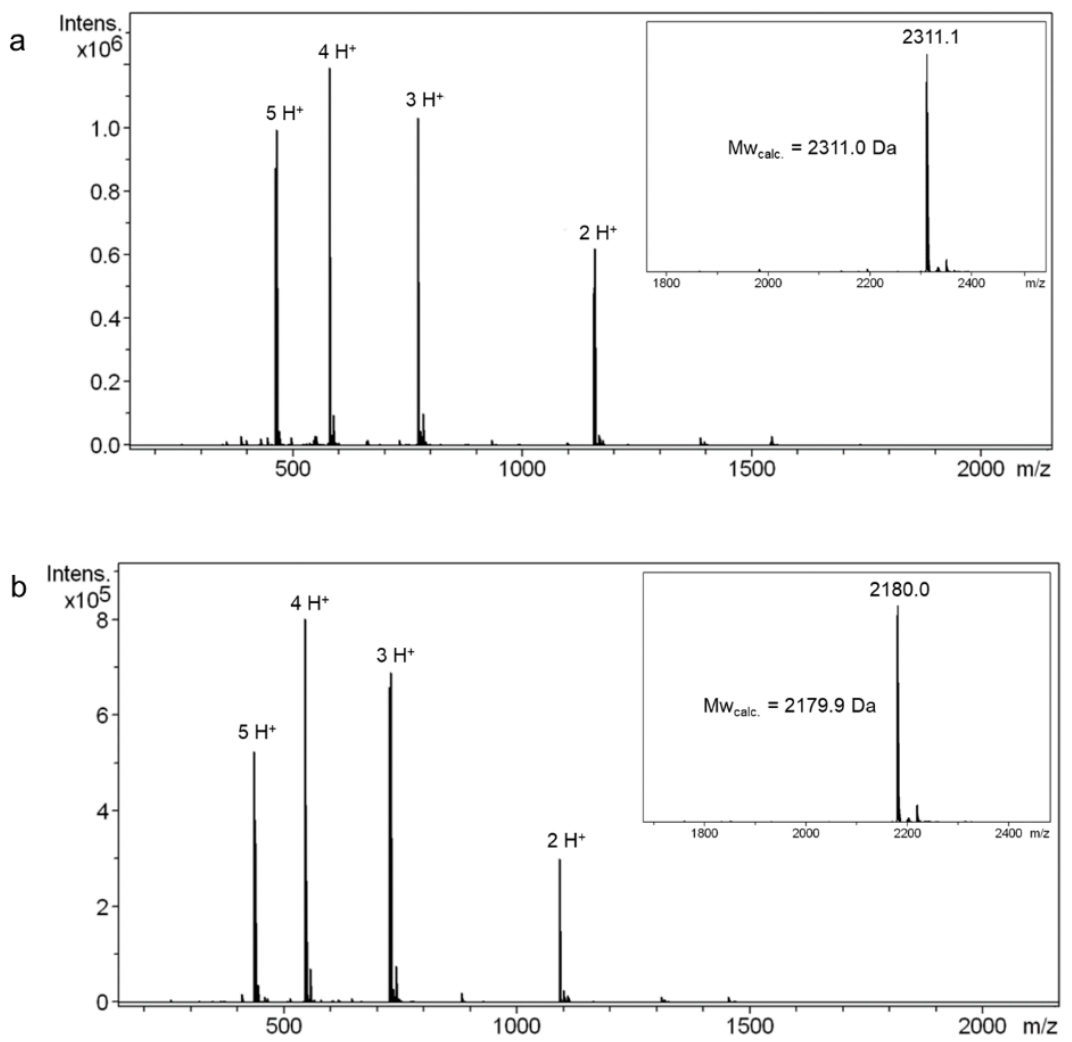

c

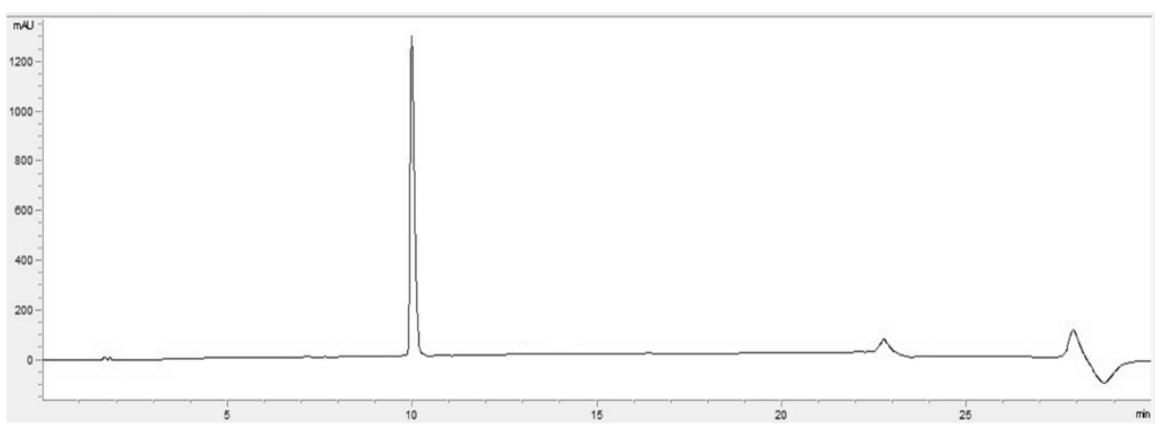

d

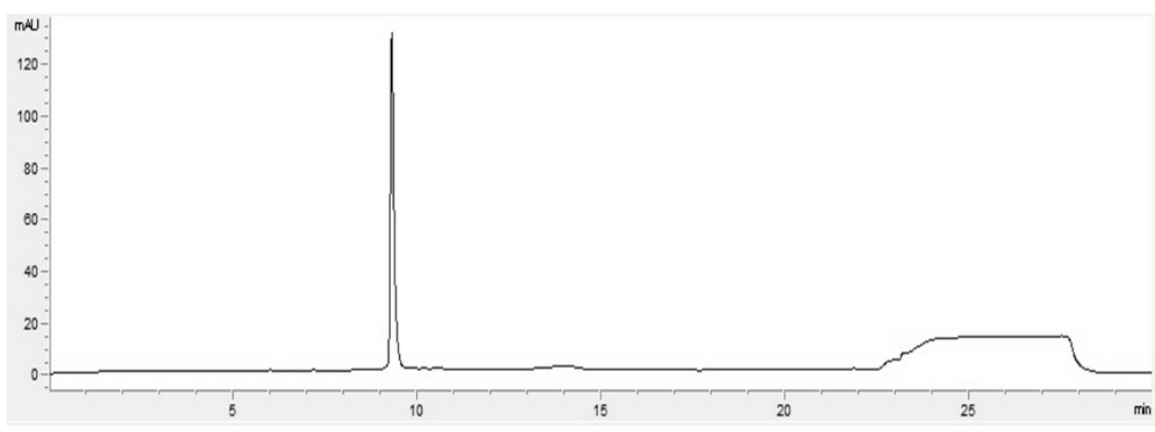

Figure S1. ADP-ribosylated peptide $\alpha$-thioesters. a, b. ESI-MS characterization of $\mathrm{H}_{2} \mathrm{~B}_{1-16} \mathrm{~S} 6 \mathrm{ADPr}$ peptide $\alpha$ thioester (a) and $\mathrm{H}_{1-14} \mathrm{~S} 10 \mathrm{ADPr}$ peptide $\alpha$-thioester (b). Inset; deconvoluted MS. c, d. RP-HPLC chromatograms of $\mathrm{H}_{2} \mathrm{~B}_{1-16} \mathrm{~S} 6 \mathrm{ADPr}$ peptide $\alpha$-thioester (c) and $\mathrm{H}_{1-14} \mathrm{~S} 10 \mathrm{ADPr}$ peptide $\alpha$-thioester (d). Mobile phase: 0-40\% HPLC solvent B gradient over 20 min. 

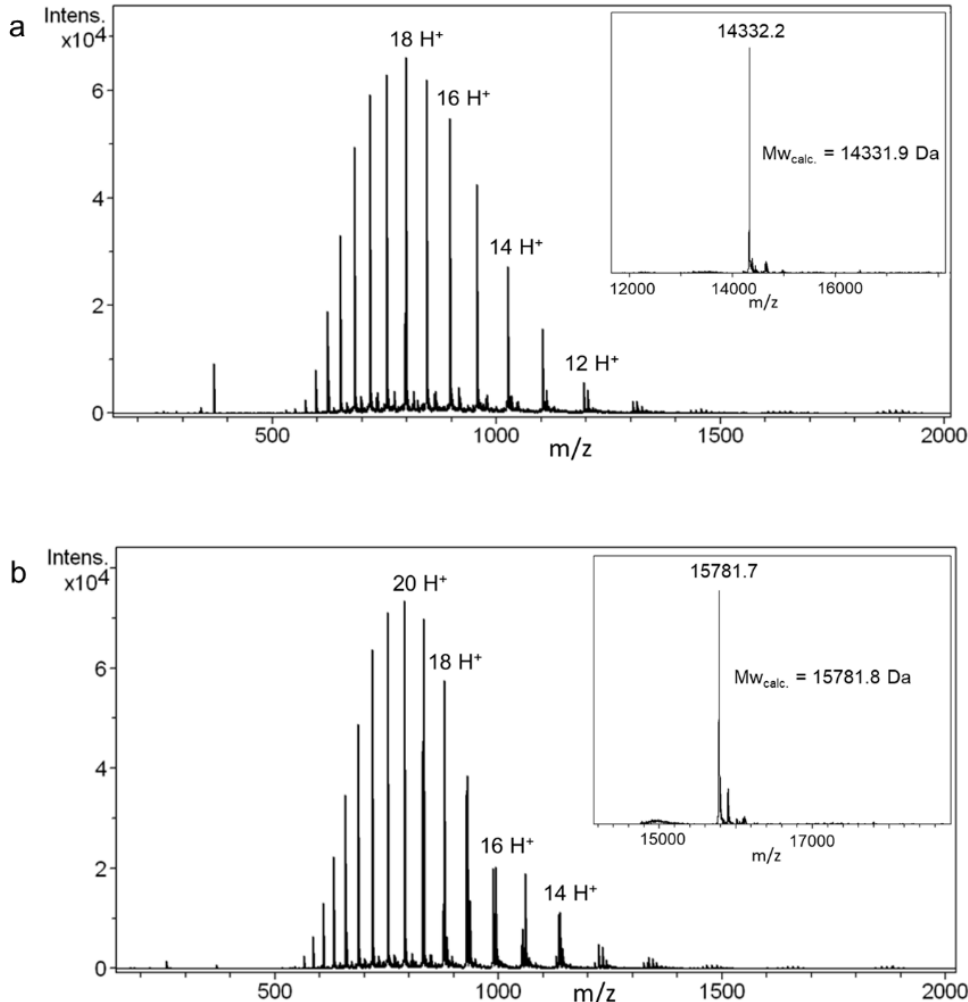

c

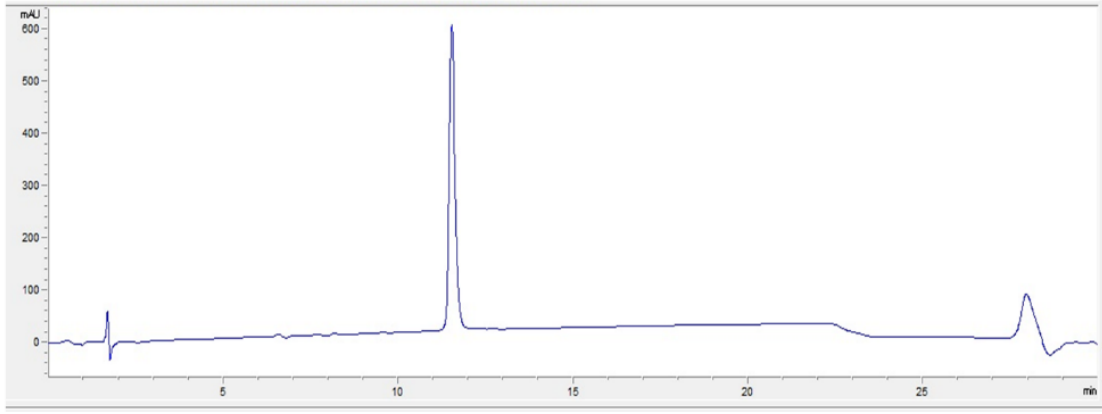

d

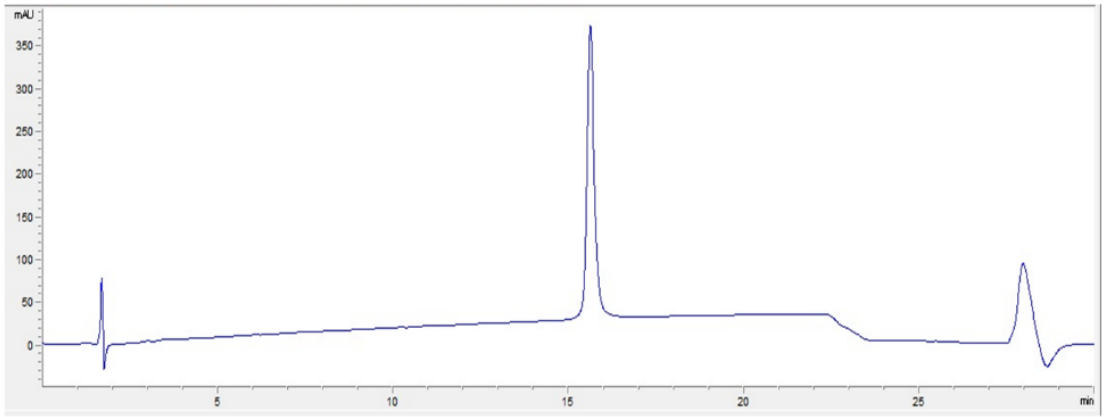

Figure S2. NCL of peptide $\alpha$-thioesters with recombinant truncated histones. a. ESI-MS characterization of the ligation product (before desulfurization) between $\mathrm{H}_{2} \mathrm{~B}_{1-16} \mathrm{~S} 6 \mathrm{ADPr}$ peptide $\alpha$-thioester and $\mathrm{H}_{2} \mathrm{~B}_{17-125} \mathrm{~A} 17 \mathrm{C}$ recombinant fragment. Inset; deconvoluted MS. b. ESI-MS characterization of the ligation product (before desulfurization) between $\mathrm{H}_{1-14} \mathrm{~S} 10 \mathrm{ADPr}$ peptide $\alpha$-thioester and $\mathrm{H} 3_{15-135} \mathrm{~A} 15 \mathrm{C}$ recombinant fragment. Inset; deconvoluted MS. c, d. RP-HPLC chromatograms of the purified native ADP-ribosylated proteins H2BS6ADPr (c) and H3S10ADPr (d). Mobile phase: 30-70\% HPLC solvent B gradient over 20 min. 


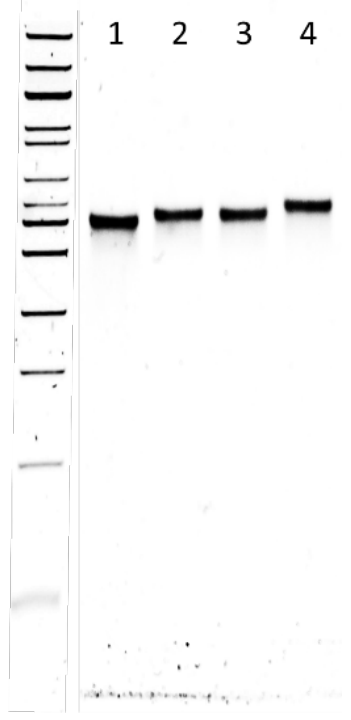

Figure S3. Native polyacrylamide gel electrophoresis of the various mononucleosomes (MNs). The presence of the ADP-ribose mark slows down the migration on the gel. 1. Unmodified MN. 2. H2BS6ADPr MN. 3. H3S10ADPr MN. 4. Dual ADPr MN.
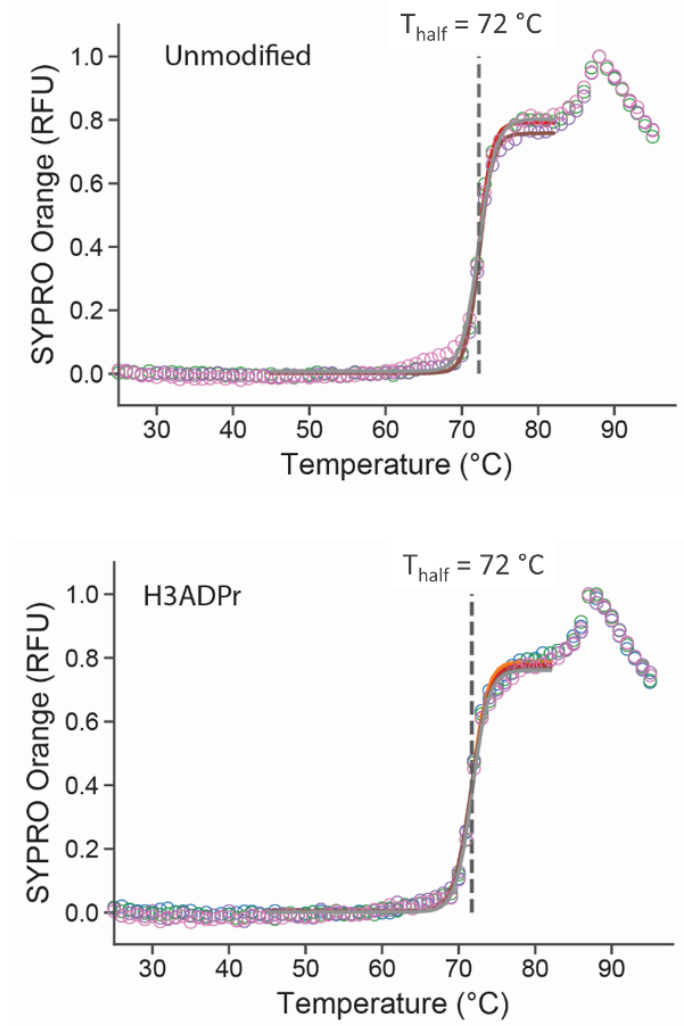

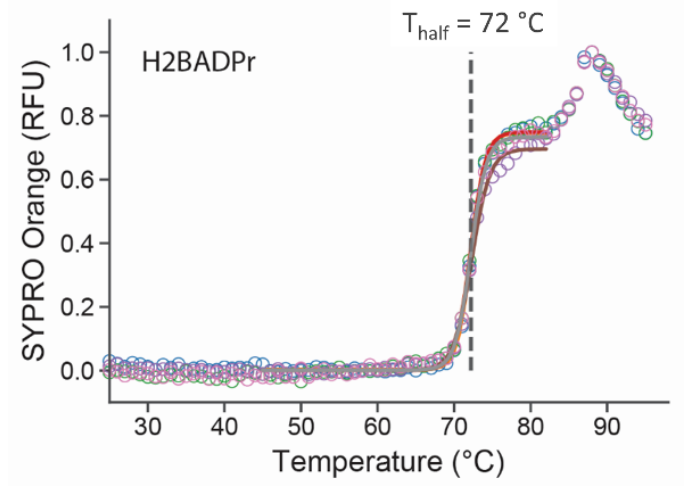

d

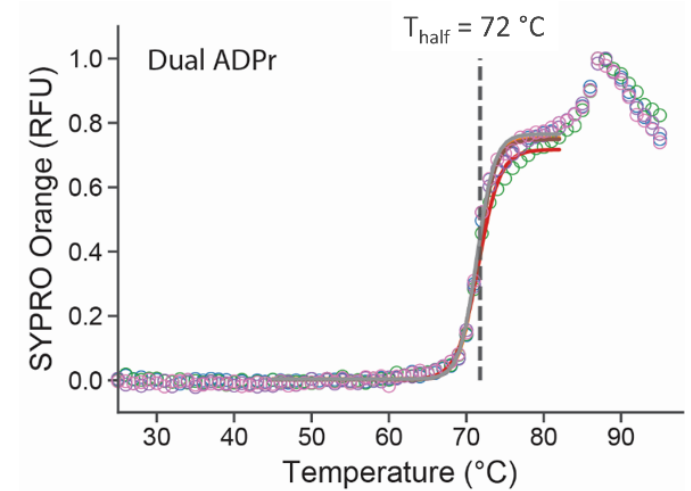

Figure S4. Melting assays of the various MNs. Normalized fluorescence intensity from the fluorescent dye SYPRO Orange is plotted as a function of temperature. Data are shown in 4 technical replicates with a sigmoidal fit. ${ }^{10} \mathrm{~T}_{\text {half }}$ is shown as a dashed vertical line. The experiment was repeated with two different batches of MNs, and similar results were obtained in both replicates $\left( \pm 0.3^{\circ} \mathrm{C}\right)$. 

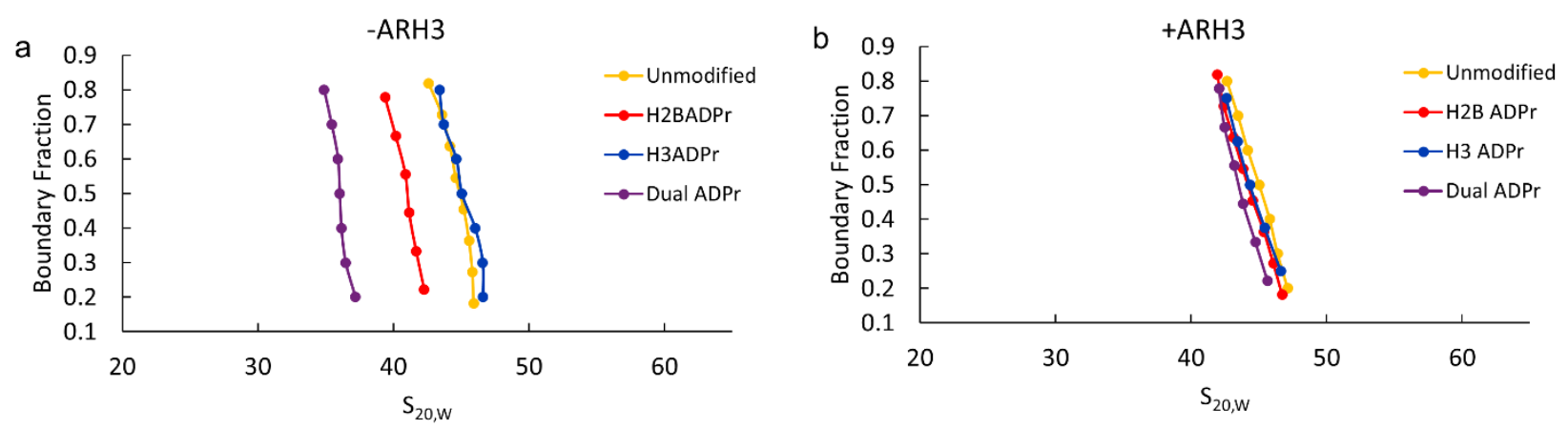

Figure S5. Removal of the ADPr mark by ARH3 restores the chromatin folding properties of the 12-mer nucleosome arrays. a. Integrated sedimentation coefficient distributions of indicated 12-mer nucleosome arrays in the presence of $1 \mathrm{mM} \mathrm{Mg}^{2+}$, as determined by sedimentation velocity experiments and van HoldeWeischet analysis. $\mathbf{b}$. The same batch of the various arrays was pre-treated with ARH3 to remove the ADPr mark, followed by sedimentation velocity experiments and van Holde-Weischet analysis.

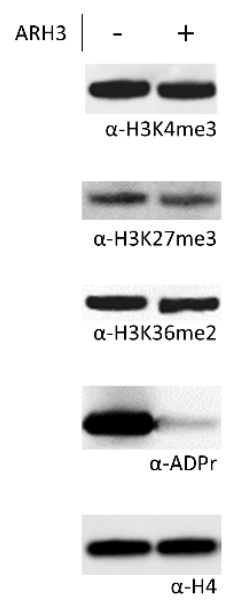

Figure S6. Antibodies against H3K4me3, H3K27me3, and H3K36me2 are insensitive to H3S10 ADPribosylation. The H3 ADP-ribosylated MN was incubated with the various KMTs for 60 min as described above ('Cold HMT assays with MLL1, PRC2 or NSD2'). Subsequently, ARH3 (1 $\mu M)$ was added to the reaction mixture, and after $5 \mathrm{~min}$ the reaction was quenched by 4 X SDS loading dye and analyzed by western blot. The removal of the ADP-ribose moiety, as indicated by the pan-ADP-ribose binding reagent (Sigma \#MABE1016), had no impact on the signal from the antibodies against H3K4me3, H3K27me3, and H3K36me2. 
a MLL1
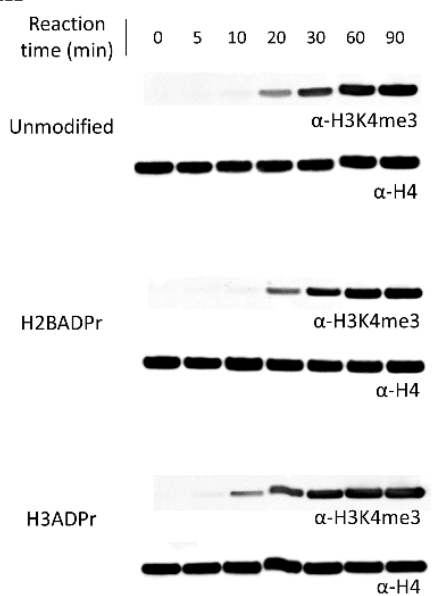

Dual ADPr

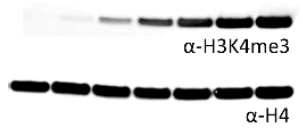

b PRC2 \begin{tabular}{c|lllllll}
$\begin{array}{c}\text { Reaction } \\
\text { time (min) }\end{array}$ & 0 & 5 & 10 & 20 & 30 & 60 & 90
\end{tabular}

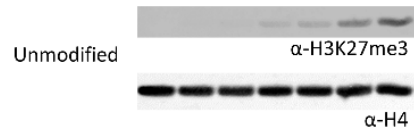

H2BADPr

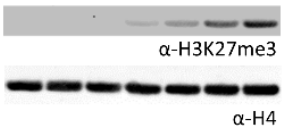

H3ADPr

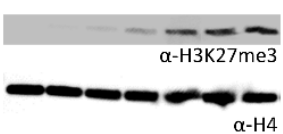

Dual ADPr
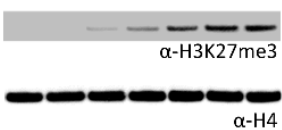

c NSD2

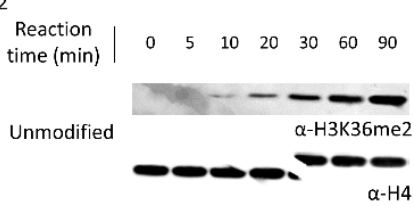

H2BADPr $\alpha-\mathrm{H} 3 \mathrm{~K} 36 \mathrm{me} 2$

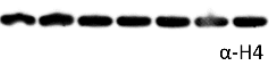

$\alpha-\mathrm{H} 4$

H3ADPr

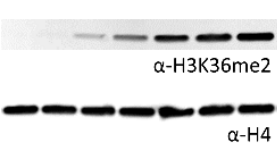

Dual ADPr

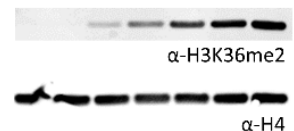

Figure S7. Histone methyltransferase assays: H3S10 ADP-ribosylation moderately increases methylation rates of MLL1 and PRC2 and does not affect methylation rate of NSD2. The various MNs were incubated with the designated lysine methyltransferase enzymes, and samples were taken at the specified time points. a-c. Western blots measuring the methyltransferase activity of MLL1 (a), PRC2 (b) and NSD2 (c). In each case, H4 was used as a loading control. 


\section{Synthetic protocols}

\section{General methods for organic synthesis}

All reactions were carried out at room temperature unless stated otherwise. Chemicals and solvents were purchased from Sigma-Aldrich unless stated otherwise and were used without further purification. Thin layer chromatography (TLC): silica gel plates Merck $60 \mathrm{~F}_{254}$ : compounds were visualized by irradiation with UV light. Silica gel chromatography was performed on Sigma silica gel, pore size $60 \AA$, 230-400 mesh particle size. NMR spectra were recorded on a Bruker Avance operated at $500 \mathrm{MHz}$ (for ${ }^{1} \mathrm{H}$ NMR). Chemical shifts were reported in ppm on the $\delta$ scale relative to a residual solvent $\left(\mathrm{CDCl}_{3}: \delta=7.26\right.$ for ${ }^{1} \mathrm{H}-\mathrm{NMR}$ and 77.16 for ${ }^{13} \mathrm{C}-\mathrm{NMR}, \mathrm{D}_{2} \mathrm{O}: \delta$ $=4.79$ for $\left.{ }^{1} \mathrm{H}-\mathrm{NMR}\right)$. High-resolution mass spectrometry was performed on an Agilent 6220 Accurate-Mass Time-of-Flight LC/MS with electrospray ionization. Abbreviations: MeCN - acetonitrile, DCM dichloromethane, EtOAc - ethyl acetate, Hex - hexanes, $\mathrm{MeOH}$ - methanol, TFA - trifluoroacetic acid.

\section{Synthesis of phosphoribosylated serine derivative 1}
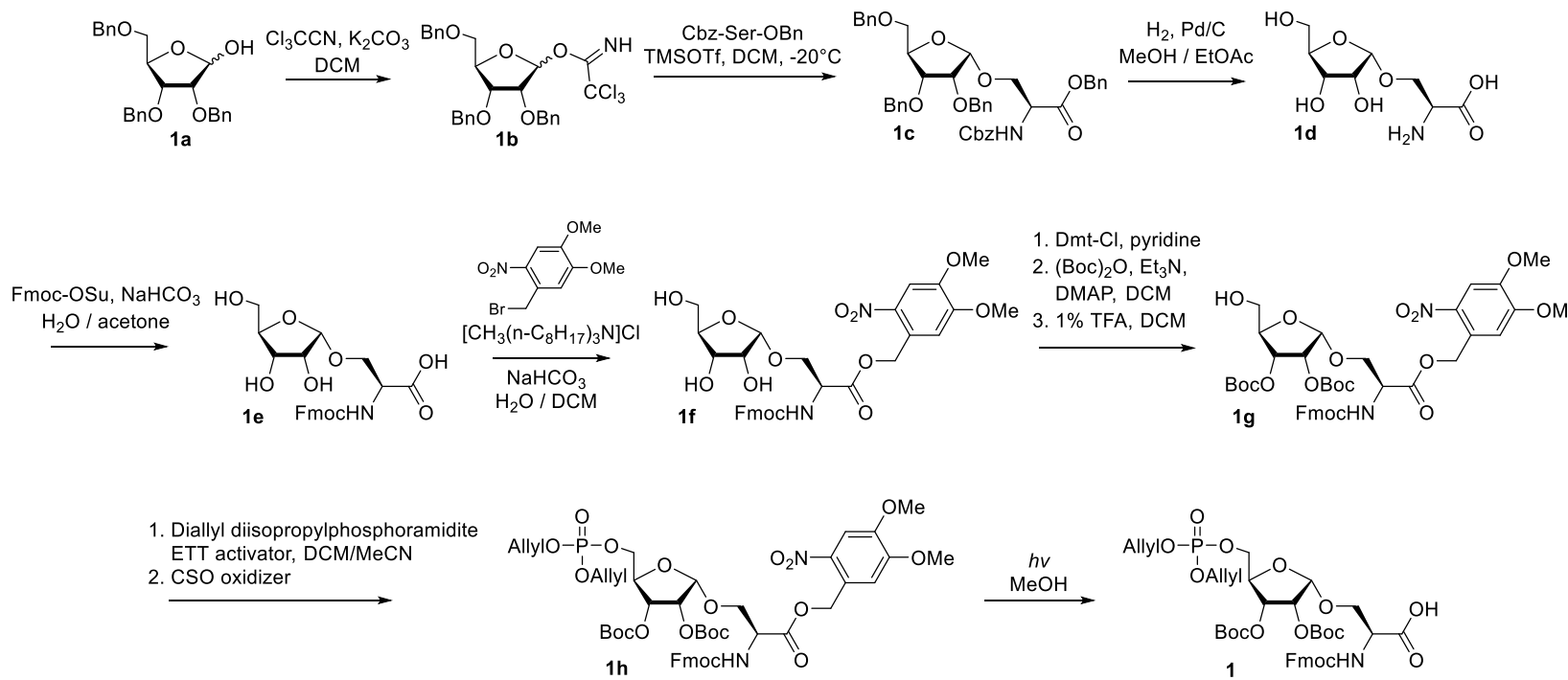

\section{Compound $\mathbf{1 b}$}

2,3,5-tri-O-benzyl-D-ribofuranose 1 a was synthesized as reported previously, ${ }^{18}$ and was purified by silica gel chromatography (Hex:EtOAc 50:50). 1a (8.64 gr, $20.57 \mathrm{mmol}$ ) was dissolved in $60 \mathrm{~mL}$ of DCM. $20.6 \mathrm{~mL}$ (10 eq) of trichloroacetonitrile were added, followed by the addition of $3.4 \mathrm{~g} \mathrm{~K}_{2} \mathrm{CO}_{3}(1.2 \mathrm{eq})$. The reaction was stirred at RT overnight, after which TLC (70:30 Hex:EtOAc, 2\% $\left.\mathrm{Et}_{3} \mathrm{~N}\right)$ showed conversion to a less polar compound. The solid particles were filtered off using a sintered glass filter, and solvents were evaporated under reduced pressure to afford a yellowish oil. The resulting trichloroacetimidate $\mathbf{1 b}$ was taken to the next step without further purification. 


\section{Compound 1c}

Trichloroacetimidate $\mathbf{1 b}$ (20.57 mmol - quantitatively from previous step) was dissolved in $50 \mathrm{~mL}$ of dry DCM. Z-L-serine benzyl ester (6.8 gr, 1 eq, Chem-Impex \# 02251) and $1 \mathrm{~g}$ of freshly activated molecular sieves were added, and the solution was stirred under argon at RT for $5 \mathrm{~min}$. Subsequently, the solution was cooled down to $-20^{\circ} \mathrm{C}$ (salt-ice bath), and trimethylsilyl triflate $(560 \mu \mathrm{L}, 0.15 \mathrm{eq})$ was added. The reaction was stirred for 30 $\min$ at $-20^{\circ} \mathrm{C}$, and then quenched by $1 \mathrm{~mL}$ of $\mathrm{Et}_{3} \mathrm{~N}$. TLC (Hex:EtOAc 75:25) showed full conversion of starting materials to products with $\mathrm{Rf}$ between the glycosyl donor (1) and acceptor; about 3:1 ratio of $\alpha$ to $\beta$ anomers. The anomeric configuration was assigned by ${ }^{1} \mathrm{H} N \mathrm{NMR}$, based on the coupling constant of the anomeric proton $\left(\alpha: d, J=4.1 \mathrm{~Hz}, \beta: s\right.$; see ${ }^{1} \mathrm{H}$ NMR spectra in pages S21-S22), which was in accordance with similar serine-ribose glycosylation products reported previously. ${ }^{19}$ Solvents were evaporated under reduced pressure. Purification by silica gel chromatography (Hex:EtOAc 65:35) afforded $8.8 \mathrm{gr}$ of the desired $\alpha$ anomer as a colorless oil (58\% yield). ${ }^{1} \mathrm{H}$ NMR $\left(500 \mathrm{MHz}, \mathrm{CDCl}_{3}\right)$ 8 $7.37-7.19(\mathrm{~m}, 25 \mathrm{H}), 6.36(\mathrm{~d}, \mathrm{~J}=9.0 \mathrm{~Hz}, 1 \mathrm{H}), 5.18-5.03(\mathrm{~m}, 4 \mathrm{H}), 4.94(\mathrm{~d}, \mathrm{~J}$ $=4.1 \mathrm{~Hz}, 1 \mathrm{H}), 4.69-4.38(\mathrm{~m}, 7 \mathrm{H}), 4.23(\mathrm{q}, \mathrm{J}=3.6 \mathrm{~Hz}, 1 \mathrm{H}), 4.15(\mathrm{dd}, \mathrm{J}=10.5,3.1 \mathrm{~Hz}, 1 \mathrm{H}), 3.95(\mathrm{dd}, \mathrm{J}=10.5,3.2$ $\mathrm{Hz}, 1 \mathrm{H}), 3.86(\mathrm{dd}, \mathrm{J}=6.3,3.0 \mathrm{~Hz}, 1 \mathrm{H}), 3.79(\mathrm{dd}, \mathrm{J}=6.3,4.0 \mathrm{~Hz}, 1 \mathrm{H}), 3.42(\mathrm{dd}, \mathrm{J}=10.6,3.8 \mathrm{~Hz}, 1 \mathrm{H}), 3.35(\mathrm{dd}, \mathrm{J}=$ 10.6, 3.9 Hz, 1H). ${ }^{13} \mathrm{C} \mathrm{NMR}(126 \mathrm{MHz}, \mathrm{CDCl} 3) \delta 170.48,156.53,138.24,137.97,137.89,136.63,135.64,128.61$, $128.52,128.51,128.49,128.37,128.28,128.17,128.12,128.08,128.05,127.98,127.93,127.81,127.70$, $127.67,101.21,82.40,78.41,75.64,73.53,72.54,72.51,69.95,67.76,67.19,66.89,54.69 . \mathrm{HRMS}[\mathrm{M}+\mathrm{Na}]^{+}$ calculated for $\mathrm{C}_{44} \mathrm{H}_{45} \mathrm{NO}_{9}:$ 731.30943, found: 731.30998 .

\section{Compound 1d}

Glycosylation product 1c ( $8.8 \mathrm{gr}, 12 \mathrm{mmol})$ was dissolved in $8 \mathrm{~mL}$ of EtOAc, followed by the addition of $72 \mathrm{~mL}$ of $\mathrm{MeOH} .1 \mathrm{gr}$ of Palladium on carbon (10\% wt. loading, Sigma \#205699) was added and the reaction was stirred under hydrogen atmosphere (using hydrogen balloon) overnight. The product precipitated as a white solid in the solution. $40 \mathrm{~mL}$ of water were added to solubilize the product, and the catalyst was filtered off using a sintered glass filter. Methanol was evaporated under reduced pressure, followed by lyophilization of the water, to afford the product as a white powder $\left(2.85 \mathrm{gr}\right.$, quantitative yield). ${ }^{1} \mathrm{H} N \mathrm{NMR}\left(500 \mathrm{MHz}, \mathrm{D}_{2} \mathrm{O}\right) \delta$ $5.10(\mathrm{~d}, J=4.4 \mathrm{~Hz}, 1 \mathrm{H}), 4.16(\mathrm{dd}, J=11.1,3.2 \mathrm{~Hz}, 1 \mathrm{H}), 4.14-4.10(\mathrm{~m}, 2 \mathrm{H}), 4.04(\mathrm{dd}, J=6.4,3.3 \mathrm{~Hz}, 1 \mathrm{H}), 4.02$ (dd, $J=5.8,3.1 \mathrm{~Hz}, 1 \mathrm{H}$ ), 3.92 (dd, $J=11.1,5.8 \mathrm{~Hz}, 1 \mathrm{H}$ ), 3.73 (dd, $J=12.4,3.3 \mathrm{~Hz}, 1 \mathrm{H}$ ), 3.64 (dd, $J=12.4,4.8 \mathrm{~Hz}$, 1H). ${ }^{13} \mathrm{C}$ NMR $\left(126 \mathrm{MHz}, \mathrm{D}_{2} \mathrm{O}\right) \delta 172.41,102.98,85.59,72.07,69.99,67.00,62.13,55.16$. HRMS [M+H] ${ }^{+}$ calculated for $\mathrm{C}_{8} \mathrm{H}_{15} \mathrm{NO}_{7}: 237.08485$, found: 237.08497 .

\section{Compound 1e}

$\alpha$-ribosyl serine $1 \mathbf{d}$ ( $2.85 \mathrm{gr}, 12 \mathrm{mmol}$ ) was dissolved in $15 \mathrm{~mL}$ of water, and $1.1 \mathrm{eq}$ of $\mathrm{NaHCO}_{3}$ were added (1.1 gr). Fmoc N-hydroxysuccinimide ester (1 eq, $4.05 \mathrm{gr}$ ), dissolved in $30 \mathrm{~mL}$ of acetone, was added to the aqueous solution. Reaction was stirred at RT for 3h, upon which the solution became clear, and LC-MS analysis showed full conversion to the product. Acetone was evaporated under reduced pressure, and $40 \mathrm{~mL}$ of saturated $\mathrm{NaHCO}_{3}$ solution and $60 \mathrm{~mL}$ of DCM were added. Phases were separated, and the product remained in the 
aqueous solution. Aqueous phase was acidified slowly with $1 \mathrm{M} \mathrm{HCl}$ down to $\mathrm{pH} 3$, and then extracted with EtOAc $(3 \times 100 \mathrm{~mL})$. Combined organic phases were dried over $\mathrm{MgSO}_{4}$ and evaporated under reduced pressure to afford $4.3 \mathrm{gr}$ of white solid $(9.5 \mathrm{mmol}, 79 \%$ yield), which was taken to the next step without further purification.

\section{Compound $1 \mathrm{f}$}

Compound 1 e (4.3 gr, $9.3 \mathrm{mmol})$ and $\mathrm{NaHCO}_{3}(781 \mathrm{mg}, 1 \mathrm{eq})$ were dissolved in $30 \mathrm{~mL}$ of water. To this solution was added a solution of 6-nitroveratryl bromide (3.85 gr, 1.5 eq, AstaTech \#60108) in $60 \mathrm{~mL}$ of DCM. Trioctylmethylammonium chloride (3.5 gr, Chem-Impex \#27313) was added, and the resulting mixture was stirred for 3 days at RT. Reaction progress, monitored by RP-HPLC, stopped when reached to about $80 \%$ product. $350 \mathrm{~mL}$ of EtOAc and $250 \mathrm{~mL}$ of brine were added, and phases were separated. The organic phase was dried over $\mathrm{MgSO}_{4}$ and concentrated under reduced pressure. Purification by silica gel chromatography (0-5\% MeOH in EtOAc) afforded 3.53 gr off-white powder (58\% yield). ${ }^{1} \mathrm{H}$ NMR (500 MHz, $\left.\mathrm{CDCl}_{3}\right) \delta 7.77$ (d, J $=7.6 \mathrm{~Hz}, 2 \mathrm{H}), 7.68(\mathrm{~s}, 1 \mathrm{H}), 7.60(\mathrm{~d}, \mathrm{~J}=7.6 \mathrm{~Hz}, 2 \mathrm{H}), 7.40(\mathrm{td}, \mathrm{J}=7.8,2.5 \mathrm{~Hz}, 2 \mathrm{H}), 7.31(\mathrm{t}, \mathrm{J}=7.5 \mathrm{~Hz}, 2 \mathrm{H}), 6.95(\mathrm{~s}$, $1 \mathrm{H}), 6.53(\mathrm{~d}, \mathrm{~J}=8.7 \mathrm{~Hz}, 1 \mathrm{H}), 5.62(\mathrm{~d}, \mathrm{~J}=13.8 \mathrm{~Hz}, 1 \mathrm{H}), 5.53(\mathrm{~d}, \mathrm{~J}=13.8 \mathrm{~Hz}, 1 \mathrm{H}), 5.04(\mathrm{~d}, \mathrm{~J}=4.3 \mathrm{~Hz}, 1 \mathrm{H}), 4.62(\mathrm{dt}$, $\mathrm{J}=8.9,3.1 \mathrm{~Hz}, 1 \mathrm{H}), 4.45(\mathrm{dd}, \mathrm{J}=10.6,7.0 \mathrm{~Hz}, 1 \mathrm{H}), 4.33(\mathrm{dd}, \mathrm{J}=10.6,7.4 \mathrm{~Hz}, 1 \mathrm{H}), 4.21-4.10(\mathrm{~m}, 4 \mathrm{H}), 4.09-$ $4.00(\mathrm{~m}, 2 \mathrm{H}), 3.96(\mathrm{~s}, 3 \mathrm{H}), 3.94(\mathrm{~s}, 3 \mathrm{H}), 3.83-3.74(\mathrm{~m}, 1 \mathrm{H}), 3.74-3.66(\mathrm{~m}, 1 \mathrm{H}), 3.28(\mathrm{~d}, \mathrm{~J}=9.7 \mathrm{~Hz}, 1 \mathrm{H}), 2.95(\mathrm{~d}$, $\mathrm{J}=6.8 \mathrm{~Hz}, 1 \mathrm{H}), 1.94(\mathrm{dd}, \mathrm{J}=7.3,5.1 \mathrm{~Hz}, 1 \mathrm{H}) .{ }^{13} \mathrm{C} \mathrm{NMR}\left(126 \mathrm{MHz}, \mathrm{CDCl}_{3}\right) \delta 170.48,156.52,153.71,148.75$, $143.99,143.72$, 141.40, 141.36, 140.21, 127.89, 127.85, 127.21, 127.19, 125.80, 125.25, 125.15, 120.13, 120.11, 111.61, 108.50, 102.16, 85.65, 72.49, 70.72, 68.44, 67.27, 65.11, 62.89, 56.74, 56.54, 54.63, 47.21. HRMS [M+Na] $]^{+}$calculated for $\mathrm{C}_{32} \mathrm{H}_{34} \mathrm{~N}_{2} \mathrm{O}_{13}: 654.20609$, found: 654.20595.

\section{Compound $1 \mathrm{~g}$}

Compound $\mathbf{1 f}$ ( $3.51 \mathrm{gr}, 5.4 \mathrm{mmol}$ ) was dissolved in $35 \mathrm{~mL}$ of dry pyridine. 4,4'-Dimethoxytrityl chloride (2.2 gr, 1.2 eq) was added, and the reaction was stirred under nitrogen atmosphere for $1 \mathrm{~h}$, upon which TLC (Hex:EtOAc 20:80) showed completion of the reaction. $10 \mathrm{~mL}$ of saturated $\mathrm{NaHCO}_{3}$ was added, followed by the addition of $150 \mathrm{~mL}$ EtOAc and $100 \mathrm{~mL}$ brine. The organic phase was dried over $\mathrm{MgSO}_{4}$ and concentrated under reduced pressure down to about $7 \mathrm{~mL}$ of viscous liquid and was taken to the next step without further purification.

DCM $(40 \mathrm{~mL})$ and $\mathrm{Et}_{3} \mathrm{~N}(3 \mathrm{~mL})$ were added to the product of the DMT-protection reaction, followed by the addition of di-tert-butyl dicarbonate $(3.93 \mathrm{gr}, 18 \mathrm{mmol})$. 4-Dimethylaminopyridine (150 mg) was added, and after $15 \mathrm{~min}$ TLC (Hex:EtOAc 50:50) showed complete conversion to a less polar compound. $100 \mathrm{~mL}$ of DCM and $100 \mathrm{~mL}$ of $1 \mathrm{M} \mathrm{HCl}$ were added. Phases were separated, and the organic phase was dried over $\mathrm{MgSO}_{4}$ and concentrated under reduced pressure. The resulting product was taken to the next step without further purification.

In order to remove the DMT protecting group from the primary alcohol, $100 \mathrm{~mL}$ of $1 \%$ TFA in DCM were added, and the solution became red immediately. $2 \mathrm{~mL}$ of $\mathrm{Et}_{3} \mathrm{SiH}$ were added, and the reaction was stirred until the 
red color disappeared ( 1 h). $100 \mathrm{~mL}$ of brine were added, and phases were separated. The organic phase was dried over $\mathrm{MgSO}_{4}$ and concentrated under reduced pressure. Purification by silica gel chromatography (Hex:EtOAc 30:70) afforded $2.3 \mathrm{gr}$ of white solid (50\% yield over 3 steps). ${ }^{1} \mathrm{H}$ NMR $\left(500 \mathrm{MHz}, \mathrm{CDCl}_{3}\right) \delta 7.76$ (d, $J=7.6 \mathrm{~Hz}, 2 \mathrm{H}), 7.69(\mathrm{~s}, 1 \mathrm{H}), 7.60(\mathrm{t}, J=6.4 \mathrm{~Hz}, 2 \mathrm{H}), 7.39(\mathrm{td}, J=7.4,5.1 \mathrm{~Hz}, 2 \mathrm{H}), 7.32-7.25(\mathrm{~m}, 2 \mathrm{H}), 7.04(\mathrm{~s}$, 1H), $6.35(\mathrm{~d}, J=9.1 \mathrm{~Hz}, 1 \mathrm{H}), 5.69(\mathrm{~d}, J=15.1 \mathrm{~Hz}, 1 \mathrm{H}), 5.58(\mathrm{~d}, J=15.0 \mathrm{~Hz}, 1 \mathrm{H}), 5.23(\mathrm{~d}, J=4.5 \mathrm{~Hz}, 1 \mathrm{H}), 5.08(\mathrm{dd}$, $J=6.9,3.5 \mathrm{~Hz}, 1 \mathrm{H}), 4.89(\mathrm{dd}, J=6.9,4.5 \mathrm{~Hz}, 1 \mathrm{H}), 4.65(\mathrm{dt}, J=9.3,3.2 \mathrm{~Hz}, 1 \mathrm{H}), 4.45-4.32(\mathrm{~m}, 3 \mathrm{H}), 4.27(\mathrm{q}, J=$ $3.3 \mathrm{~Hz}, 1 \mathrm{H}), 4.22(\mathrm{t}, J=7.3 \mathrm{~Hz}, 1 \mathrm{H}), 3.97(\mathrm{~s}, 3 \mathrm{H}), 3.94(\mathrm{~s}, 3 \mathrm{H}), 3.91-3.76(\mathrm{~m}, 3 \mathrm{H}), 1.95(\mathrm{dd}, J=7.7,4.7 \mathrm{~Hz}, 1 \mathrm{H})$, 1.47 (s, 9H), 1.39 (s, 9H). ${ }^{13} \mathrm{C} \mathrm{NMR}\left(126 \mathrm{MHz}, \mathrm{CDCl}_{3}\right) \delta 169.70,156.42,154.03,153.09,152.52,148.23,143.94$, $143.77,141.41,141.39,139.66,127.88,127.87,127.21,127.19,125.28,125.24,120.12,120.10,110.15$, $108.00,101.64,83.33,83.11,82.63,73.03,71.95,70.03,67.24,64.12,62.21,56.92,56.49,54.86,47.25,27.74$, 27.68. HRMS $[\mathrm{M}+\mathrm{Na}]^{+}$calculated for $\mathrm{C}_{42} \mathrm{H}_{50} \mathrm{~N}_{2} \mathrm{O}_{17}: 854.31095$, found: 854.31157 .

\section{Compound $1 \mathrm{~h}$}

Compound $1 \mathrm{~g}$ ( $850 \mathrm{mg}, 1 \mathrm{mmol}$ ) was dissolved in $8 \mathrm{~mL}$ of dry DCM under argon atmosphere. ETT activator ( $0.25 \mathrm{M}$ in MeCN, $8 \mathrm{~mL}, 2 \mathrm{eq}$ ) was added, followed by the addition of diallyl N,N-diisopropylphosphoramidite (320 $\mu \mathrm{L}, 1.2 \mathrm{eq)}$ ). After $10 \mathrm{~min}$, TLC (Hex:EtOAc 50:50) showed complete conversion to a less polar compound. The reaction was cooled down to $0^{\circ} \mathrm{C}$, and CSO oxidizer (0.1M in MeCN, $20 \mathrm{~mL}$, 2 eq, Glen Research \#40-463152) was added. After 30 min of stirring, TLC (Hex:EtOAc 30:70) showed full conversion to a more polar compound. $10 \mathrm{~mL}$ of saturated $\mathrm{NaHCO}_{3}$ were added, followed by the addition of $150 \mathrm{~mL}$ EtOAc and $120 \mathrm{~mL}$ of brine. Phases were separated, and the organic phase was dried over $\mathrm{MgSO}_{4}$ and concentrated under reduced pressure. Purification by silica gel chromatography (Hex:EtOAc 30:70) afforded the product as a white solid (800 mg, 79\% yield). ${ }^{1} \mathrm{H}$ NMR $\left(500 \mathrm{MHz}, \mathrm{CDCl}_{3}\right) \delta 7.75(\mathrm{~d}, J=7.6 \mathrm{~Hz}, 2 \mathrm{H}), 7.69(\mathrm{~s}, 1 \mathrm{H}), 7.60(\mathrm{t}, J=8.0 \mathrm{~Hz}, 2 \mathrm{H})$, $7.38(\mathrm{q}, J=7.0 \mathrm{~Hz}, 2 \mathrm{H}), 7.31-7.26(\mathrm{~m}, 2 \mathrm{H}), 7.04(\mathrm{~s}, 1 \mathrm{H}), 6.31(\mathrm{~d}, J=9.1 \mathrm{~Hz}, 1 \mathrm{H}), 5.93(\mathrm{ddt}, J=16.1,10.7,5.6$ $\mathrm{Hz}, 2 \mathrm{H}), 5.68(\mathrm{~d}, J=15.1 \mathrm{~Hz}, 1 \mathrm{H}), 5.60(\mathrm{~d}, J=15.1 \mathrm{~Hz}, 1 \mathrm{H}), 5.41-5.32(\mathrm{~m}, 2 \mathrm{H}), 5.28(\mathrm{~d}, J=4.4 \mathrm{~Hz}, 1 \mathrm{H}), 5.26-$ $5.22(\mathrm{~m}, 2 \mathrm{H}), 5.13(\mathrm{dd}, J=6.7,3.0 \mathrm{~Hz}, 1 \mathrm{H}), 4.88(\mathrm{dd}, J=6.8,4.4 \mathrm{~Hz}, 1 \mathrm{H}), 4.67(\mathrm{dd}, J=9.1,3.3 \mathrm{~Hz}, 1 \mathrm{H}), 4.56$ (dddt, $J=8.4,5.6,4.2,1.4 \mathrm{~Hz}, 4 \mathrm{H}), 4.42-4.35(\mathrm{~m}, 2 \mathrm{H}), 4.34-4.28(\mathrm{~m}, 2 \mathrm{H}), 4.28-4.25(\mathrm{~m}, 2 \mathrm{H}), 4.22(\mathrm{t}, J=7.5$ $\mathrm{Hz}, 1 \mathrm{H}), 3.97(\mathrm{~s}, 3 \mathrm{H}), 3.95-3.92(\mathrm{~m}, 4 \mathrm{H}), 1.46(\mathrm{~s}, 9 \mathrm{H}), 1.39(\mathrm{~s}, 9 \mathrm{H}) .{ }^{13} \mathrm{C} \mathrm{NMR}\left(126 \mathrm{MHz}, \mathrm{CDCl}_{3}\right) \delta$ 169.69, 156.45, $154.03,152.88,152.36,148.22,143.90,143.77,141.37,141.35,139.65,132.43,132.41,132.37,132.36$, $127.88,127.23,127.19,125.33,125.23,120.13,118.74,118.73,110.07,108.00,101.49,83.32,83.17,80.85$, $80.78,72.84,71.73,69.69,68.60,68.55,67.47,66.64,66.60,64.09,56.89,56.49,54.82,47.17,27.72,27.67$. HRMS $[\mathrm{M}+\mathrm{H}]^{+}$calculated for $\mathrm{C}_{48} \mathrm{H}_{59} \mathrm{~N}_{2} \mathrm{O}_{20} \mathrm{P}: 1014.33989$, found: 1014.34050 .

\section{Compound 1}

Compound $1 \mathrm{~h}$ ( $800 \mathrm{mg}, 0.79 \mathrm{mmol})$ was dissolved in methanol $(100 \mathrm{~mL})$, and the solution was irradiated with $370 \mathrm{~nm}$ UV light at RT (Lamp: Kessil PR160-370 nm). Reaction was monitored by RP-HPLC and reached to about $90 \%$ completion after 10 hours of irradiation, upon which the solvent was evaporated, and the product was purified by RP-HPLC. The solvents were lyophilized, and compound $\mathbf{1}$ was obtained as a white solid (300 mg, 
$47 \%$ yield). ${ }^{1} \mathrm{H}$ NMR $\left(500 \mathrm{MHz}, \mathrm{CDCl}_{3}\right) \delta 7.78(\mathrm{~d}, J=7.5 \mathrm{~Hz}, 2 \mathrm{H}), 7.64(\mathrm{dd}, J=15.9,7.5 \mathrm{~Hz}, 2 \mathrm{H}), 7.45-7.38(\mathrm{~m}$, 2H), $7.35-7.29(\mathrm{~m}, 2 \mathrm{H}), 6.07(\mathrm{~d}, J=8.5 \mathrm{~Hz}, 1 \mathrm{H}), 5.95(\mathrm{ddq}, J=16.1,10.7,5.5 \mathrm{~Hz}, 2 \mathrm{H}), 5.42-5.35(\mathrm{~m}, 2 \mathrm{H}), 5.31$ $-5.26(\mathrm{~m}, 3 \mathrm{H}), 5.13(\mathrm{dd}, J=6.7,3.3 \mathrm{~Hz}, 1 \mathrm{H}), 4.92(\mathrm{dd}, J=6.7,4.4 \mathrm{~Hz}, 1 \mathrm{H}), 4.65-4.55(\mathrm{~m}, 5 \mathrm{H}), 4.43(\mathrm{dd}, J=$ $10.5,7.2 \mathrm{~Hz}, 1 \mathrm{H}), 4.38-4.31(\mathrm{~m}, 2 \mathrm{H}), 4.30-4.21(\mathrm{~m}, 3 \mathrm{H}), 4.14(\mathrm{dd}, J=10.6,3.5 \mathrm{~Hz}, 1 \mathrm{H}), 3.98(\mathrm{dd}, J=10.6,4.5$ $\mathrm{Hz}, 1 \mathrm{H}), 1.50-1.46(\mathrm{~m}, 18 \mathrm{H}) .{ }^{13} \mathrm{C}$ NMR $\left(126 \mathrm{MHz}, \mathrm{CDCl}_{3}\right) \delta 172.36,156.33,152.72,152.31,144.03,143.78$, $141.40,141.38,132.26,132.24,132.20,132.18,127.87,127.24,127.19,125.44,125.28,120.10,118.95$, $118.93,100.78,83.41,80.35,80.29,72.86,71.73,68.84,68.80,68.15,67.49,66.81,66.76,54.01,47.19,27.75$, 27.71. HRMS $[\mathrm{M}+\mathrm{Na}]^{+}$calculated for $\mathrm{C}_{39} \mathrm{H}_{50} \mathrm{NO}_{16} \mathrm{P}: 819.28673$, found: 819.28637. 


\section{Synthesis of Adenosine Phosphoramidite 2}
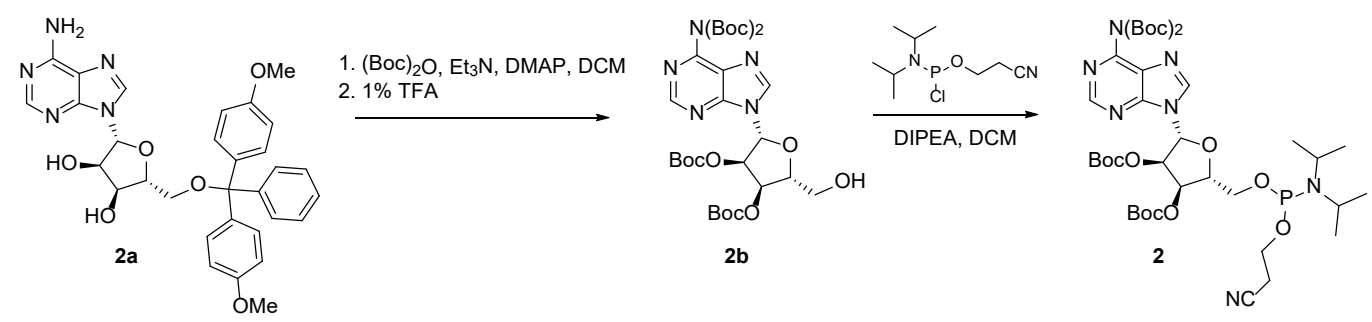

\section{Compound $2 b$}

5'-O-(4,4'-Dimethoxytrityl)adenosine 2a was purchased from Aurum Pharmatech (\#U30116). $1 \mathrm{gr}$ (1.76 mmol) of $2 \mathrm{a}$ was dissolved in $20 \mathrm{~mL}$ of DCM. $2 \mathrm{~mL}$ ( $14.3 \mathrm{mmol}, 8 \mathrm{eq}$ ) of $\mathrm{Et}_{3} \mathrm{~N}$ were added, followed by the addition of di-tert-butyl dicarbonate ( $2.3 \mathrm{gr}, 10.5 \mathrm{mmol}, 6 \mathrm{eq}$ ). 4-Dimethylaminopyridine ( $43 \mathrm{mg}, 0.2 \mathrm{eq}$ ) was added to the white suspension, and the solution became clear within few minutes. The reaction was stirred for $1 \mathrm{~h}$ at RT, upon which TLC (Hex:EtOAc 50:50) showed full conversion to the apolar per-Boc-protected product. The solution was diluted with $\mathrm{DCM}(80 \mathrm{~mL})$, washed with $1 \mathrm{M} \mathrm{HCl}(2 \times 100 \mathrm{~mL})$ and dried over $\mathrm{MgSO}_{4}$.

$1 \mathrm{~mL}$ of TFA was added to the $100 \mathrm{~mL} \mathrm{DCM}$ solution in order to remove the DMT protecting group from the primary alcohol. The solution became red immediately. $2 \mathrm{~mL}$ of $\mathrm{Et}_{3} \mathrm{SiH}$ were added, and the reaction was stirred at RT until the red color disappeared $(1 \mathrm{~h})$. Subsequently, $100 \mathrm{~mL}$ of water were added, and the organic phase was collected, dried over $\mathrm{MgSO}_{4}$, and concentrated under reduced pressure. Purification by silica gel chromatography (Hex:EtOAc 60:40) afforded compound $\mathbf{2 b}$ as a white foam ( $850 \mathrm{mg}, 73 \%$ yield). ${ }^{1} \mathrm{H}$ NMR (500 $\left.\mathrm{MHz}, \mathrm{CDCl}_{3}\right) \delta 8.85(\mathrm{~s}, 1 \mathrm{H}), 8.09(\mathrm{~s}, 1 \mathrm{H}), 6.10(\mathrm{~d}, J=7.9 \mathrm{~Hz}, 1 \mathrm{H}), 5.91(\mathrm{dd}, J=7.9,5.0 \mathrm{~Hz}, 1 \mathrm{H}), 5.82(\mathrm{dd}, J=11.7$, $2.5 \mathrm{~Hz}, 1 \mathrm{H}), 5.56(\mathrm{~d}, J=5.0 \mathrm{~Hz}, 1 \mathrm{H}), 4.45(\mathrm{~d}, J=1.8 \mathrm{~Hz}, 1 \mathrm{H}), 4.01(\mathrm{dt}, J=13.0,2.2 \mathrm{~Hz}, 1 \mathrm{H}), 3.85(\mathrm{ddd}, J=13.2$, 11.6, $1.7 \mathrm{~Hz}, 1 \mathrm{H}), 1.53$ (s, 9H), $1.46(\mathrm{~s}, 18 \mathrm{H}), 1.39$ (s, 9H). ${ }^{13} \mathrm{C} \mathrm{NMR} \mathrm{(126} \mathrm{MHz,} \mathrm{CDCl} 3$ ) $\delta$ 152.44, 152.06, 151.87, 151.54, 151.49, 150.41, 144.61, 130.65, 88.24, 85.96, 84.24, 84.00, 83.49, 74.91, 74.80, 62.91, 27.92, 27.85, 27.61. HRMS [M+Na] $]^{+}$calculated for $\mathrm{C}_{30} \mathrm{H}_{45} \mathrm{~N}_{5} \mathrm{O}_{12}: 667.30647$, found: 667.30625 .

\section{Compound 2}

Compound $\mathbf{2 b}$ ( $820 \mathrm{mg}, 1.23 \mathrm{mmol}$ ) was dissolved in $5 \mathrm{~mL}$ of dry DCM under nitrogen atmosphere. $\mathrm{N}, \mathrm{N}$ Diisopropylethylamine $(780 \mu \mathrm{L}, 4.5 \mathrm{mmol}$ ) was added, followed by the addition of 2-cyanoethyl $\mathrm{N}, \mathrm{N}$ diisopropylchlorophosphoramidite $(350 \mu \mathrm{L}, 1.39 \mathrm{mmol}$ ). After $5 \mathrm{~min}$, TLC (Hex:EtOAc 60:40) showed full conversion to a less polar compound. The solution was loaded on silica gel column, which was pre-washed with $1 \%$ pyridine in hexane. Silica gel chromatography (Hex:EtOAc 60:40,1\% pyridine) was carried out, using nitrogen as the pressing gas, to afford the product 2 as a white foam $(950 \mathrm{mg}, 89 \%$ yield; about 1 molar equivalent of pyridine remained according to ${ }^{1} \mathrm{H}$ NMR). The product was obtained as a 1:1 mixture of diastereomers at P. ${ }^{1} \mathrm{H}$ NMR $\left(500 \mathrm{MHz}, \mathrm{CDCl}_{3}\right) \delta 8.85(\mathrm{~s}, 0.5 \mathrm{H}), 8.83(\mathrm{~s}, 0.5 \mathrm{H}), 8.55(\mathrm{~s}, 0.5 \mathrm{H}), 8.52(\mathrm{~s}, 0.5 \mathrm{H}), 6.43$ $(\mathrm{d}, J=6.9 \mathrm{~Hz}, 0.5 \mathrm{H}), 6.38(\mathrm{~d}, J=6.2 \mathrm{~Hz}, 0.5 \mathrm{H}), 5.77-5.71(\mathrm{~m}, 1 \mathrm{H}), 5.52-5.45(\mathrm{~m}, 1 \mathrm{H}), 4.50-4.44(\mathrm{~m}, 1 \mathrm{H}), 4.08$ $-3.76(\mathrm{~m}, 4 \mathrm{H}), 3.67-3.58(\mathrm{~m}, 2 \mathrm{H}), 2.75-2.63(\mathrm{~m}, 2 \mathrm{H}), 1.53-1.48(\mathrm{~m}, 9 \mathrm{H}), 1.44(\mathrm{~m}, 18 \mathrm{H}), 1.40-1.36(\mathrm{~m}, 9 \mathrm{H})$, 
1.23 - $1.14(\mathrm{~m}, 12 \mathrm{H}) .{ }^{13} \mathrm{C}$ NMR $\left(126 \mathrm{MHz}, \mathrm{CDCl}_{3}\right) \delta 153.53,153.32,152.53,152.48,152.40,151.96,151.83$, $150.57,150.56,150.51,150.49,143.60,143.25,129.28,129.22,117.66,85.57,84.92,83.93,83.92,83.70$, 83.68, 83.53, 83.50, 82.85, 82.77, 82.38, 82.31, 76.11, 75.99, 74.19, 73.79, 63.09, 63.05, 62.96, 62.91, 59.03, 58.86 , 58.69, 43.43, 43.39, 43.33, 43.29, 27.94, 27.93, 27.84, 27.82, 27.65, 27.64, 24.89, 24.86, 24.83, 24.80, 24.78, 24.72, 20.42, 20.36. ${ }^{31} \mathrm{P} \mathrm{NMR}\left(203 \mathrm{MHz}, \mathrm{CDCl}_{3}\right) \delta 149.69,149.38$. HRMS $[\mathrm{M}+\mathrm{H}]^{+}$calculated for the hydrolysis product (('Pr) $)_{2} \mathrm{~N}$ is substituted by $\left.\mathrm{OH}\right) \mathrm{C}_{33} \mathrm{H}_{49} \mathrm{~N}_{6} \mathrm{O}_{14} \mathrm{P}: 784.30444$, found: 784.30526 . 
NMR Spectra

\section{Compound 1c}

\section{${ }^{1} \mathrm{H}$ NMR}

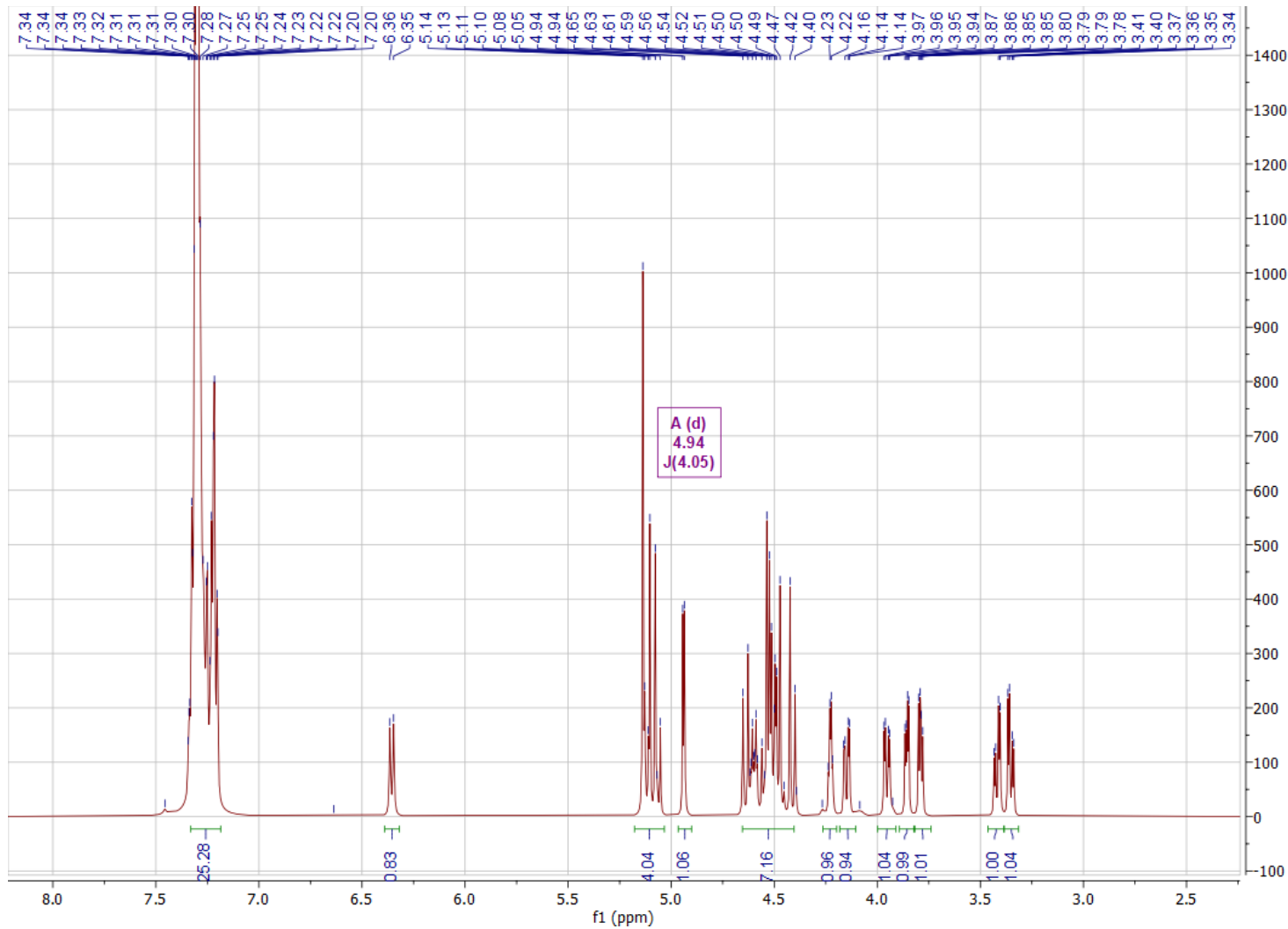

${ }^{13}$ C NMR

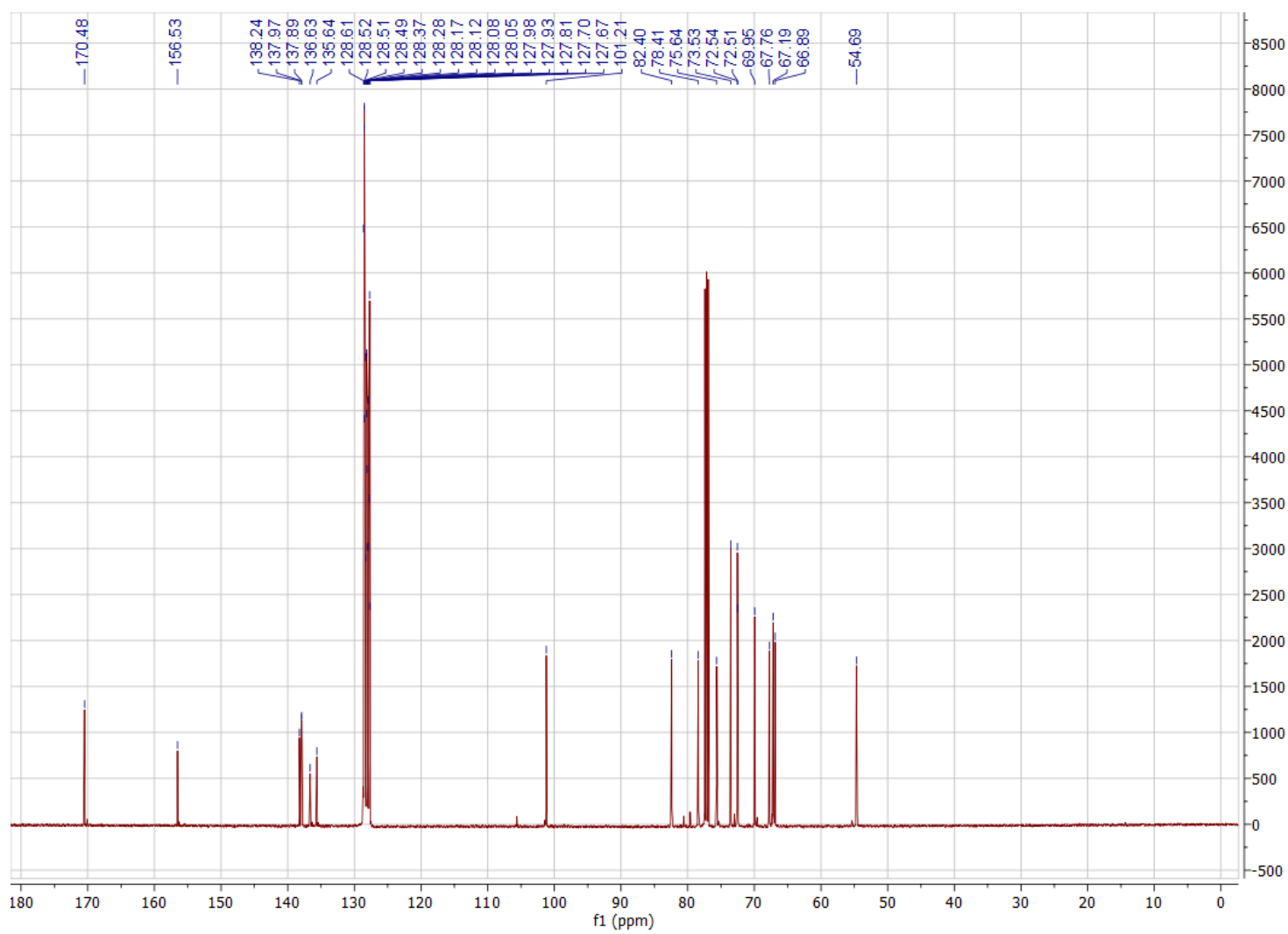


${ }^{1} \mathrm{H}$ NMR of the $\beta$-anomer glycosylation product (anomer of compound $\mathbf{1 c}$ ):

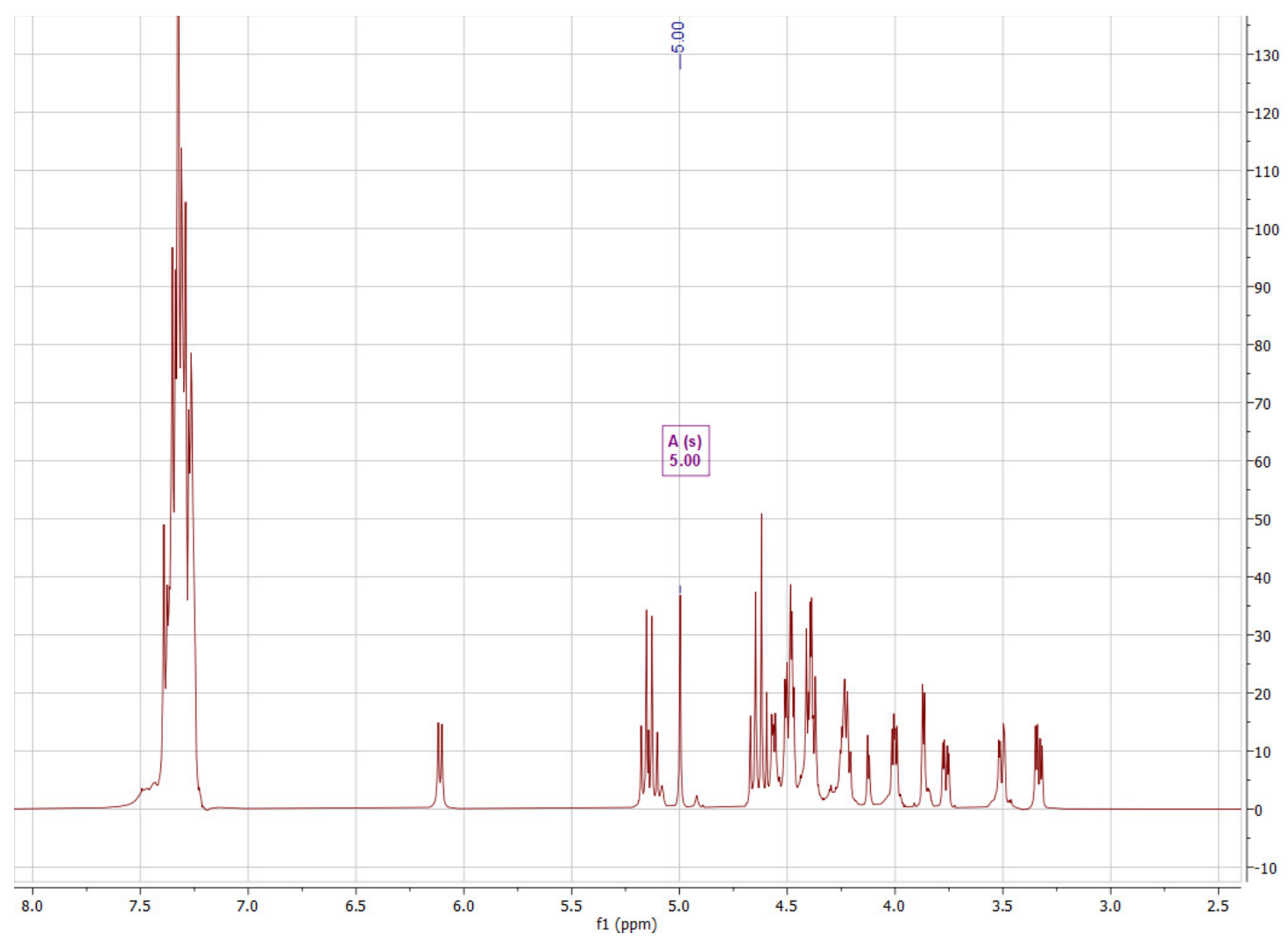


Compound 1d

${ }^{1} \mathrm{H} N M R$

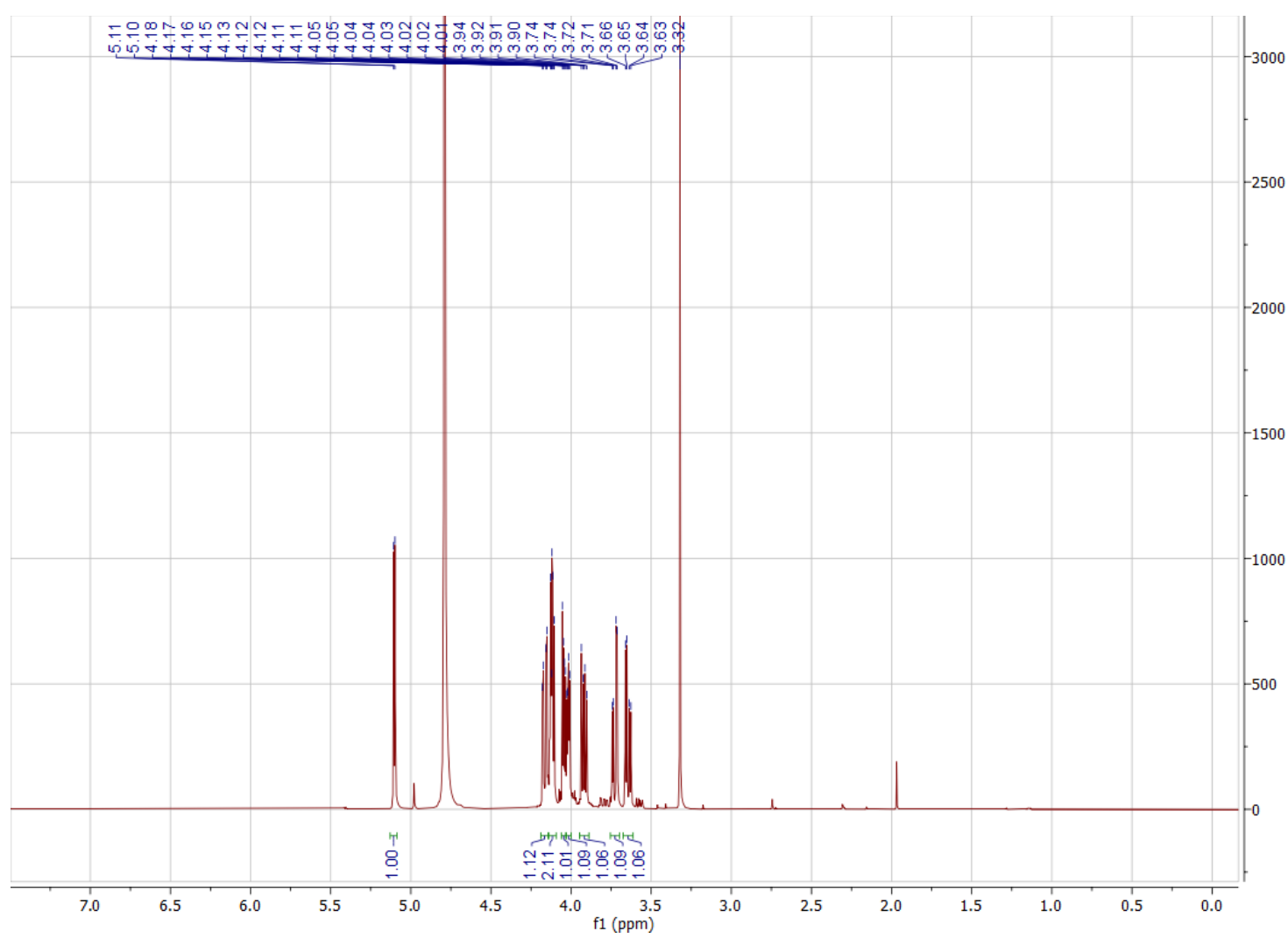

${ }^{13}$ C NMR

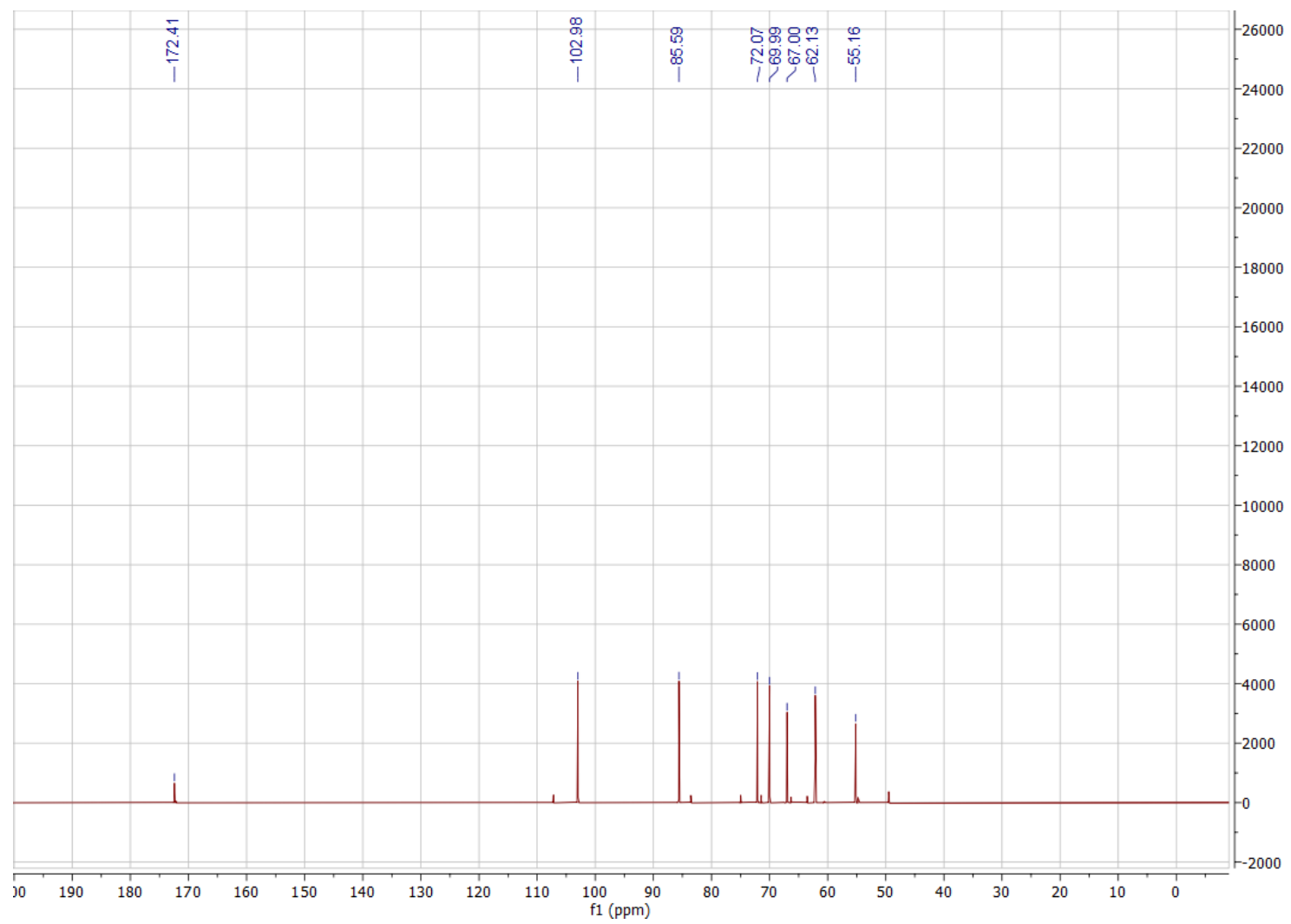




\section{Compound 1f}

\section{${ }^{1} \mathrm{H}$ NMR}

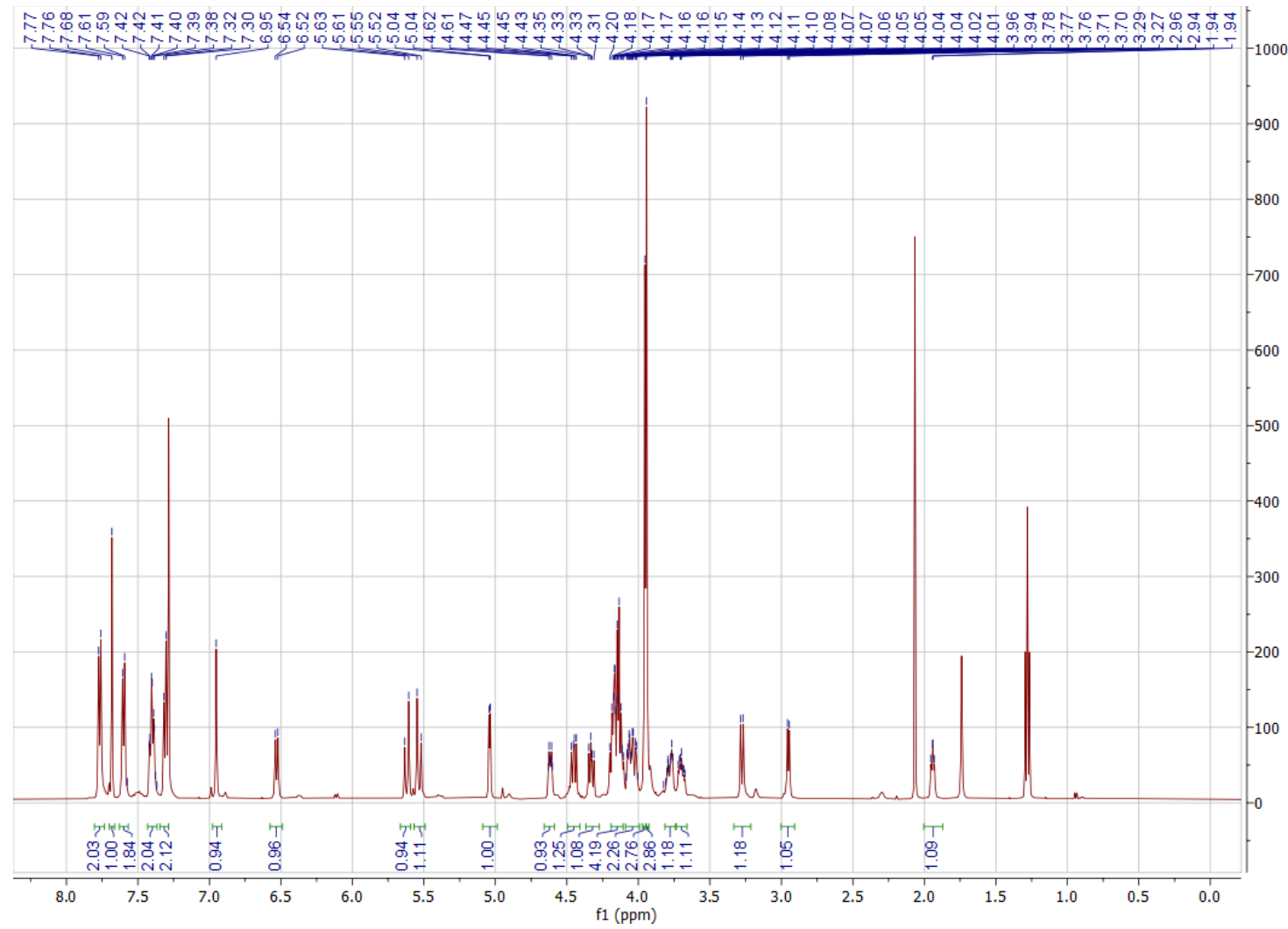

${ }^{13} \mathrm{C}$ NMR

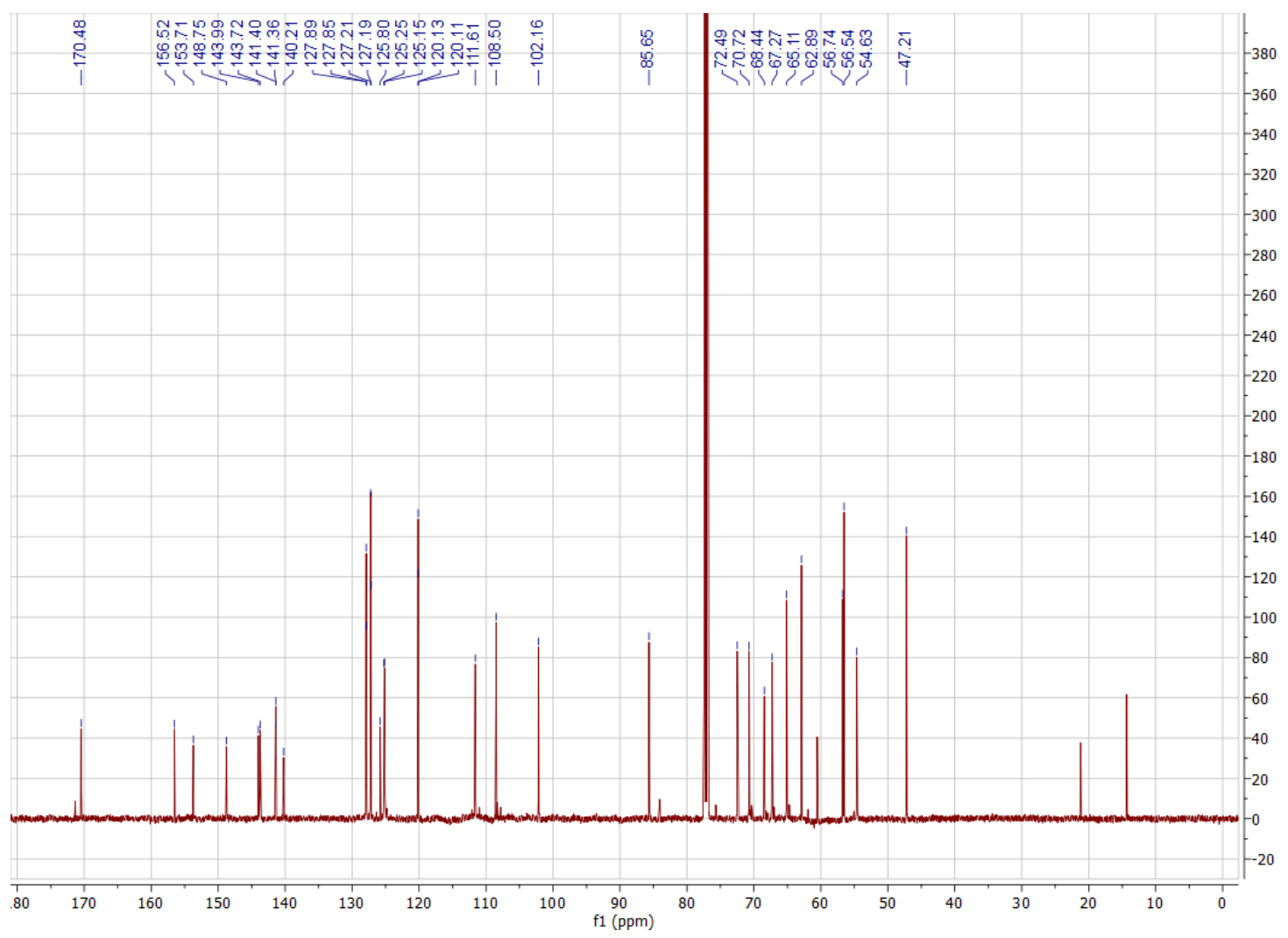




\section{Compound 1g}

\section{${ }^{1} \mathrm{H}$ NMR}

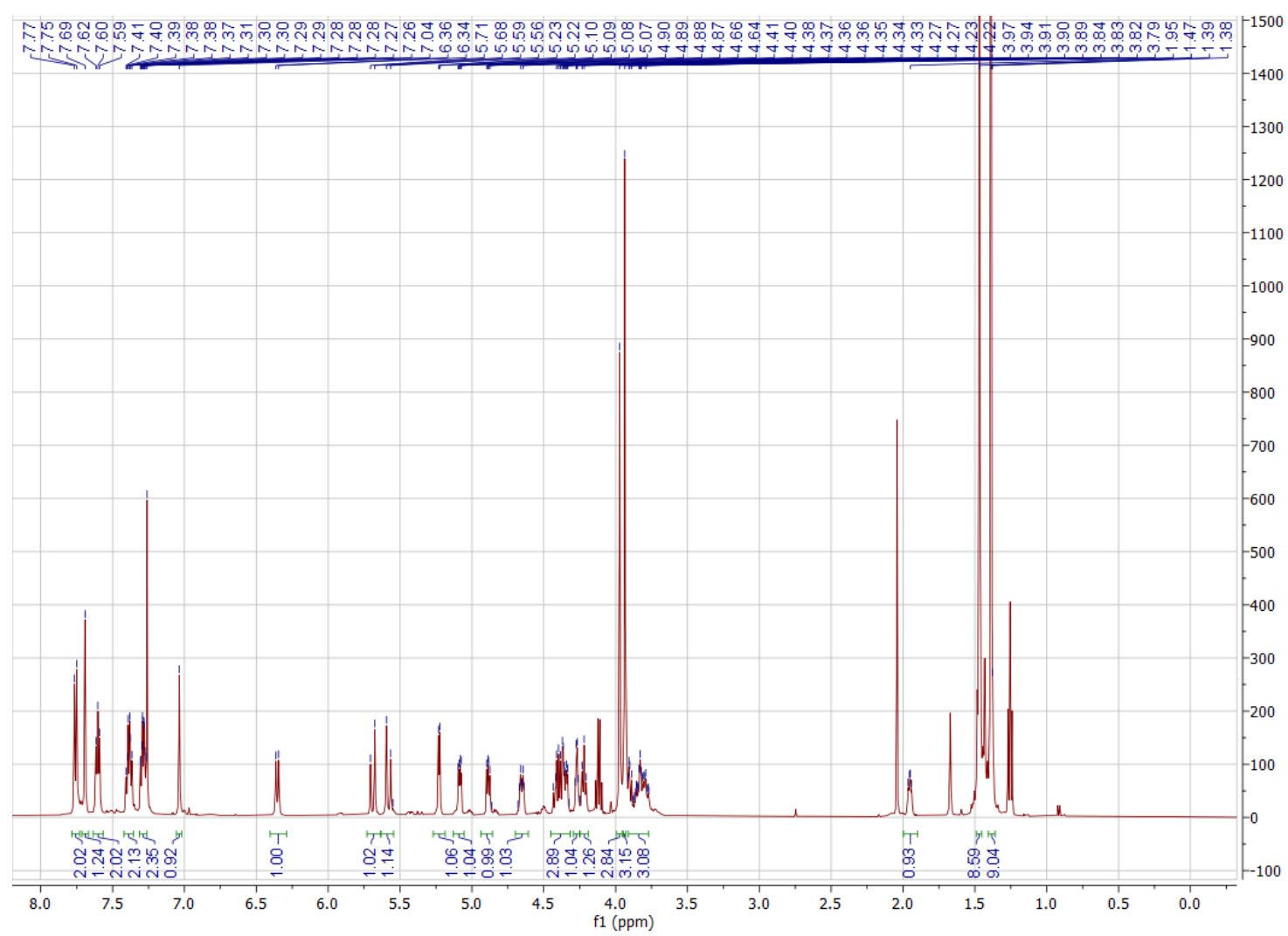

${ }^{13} \mathrm{C}$ NMR

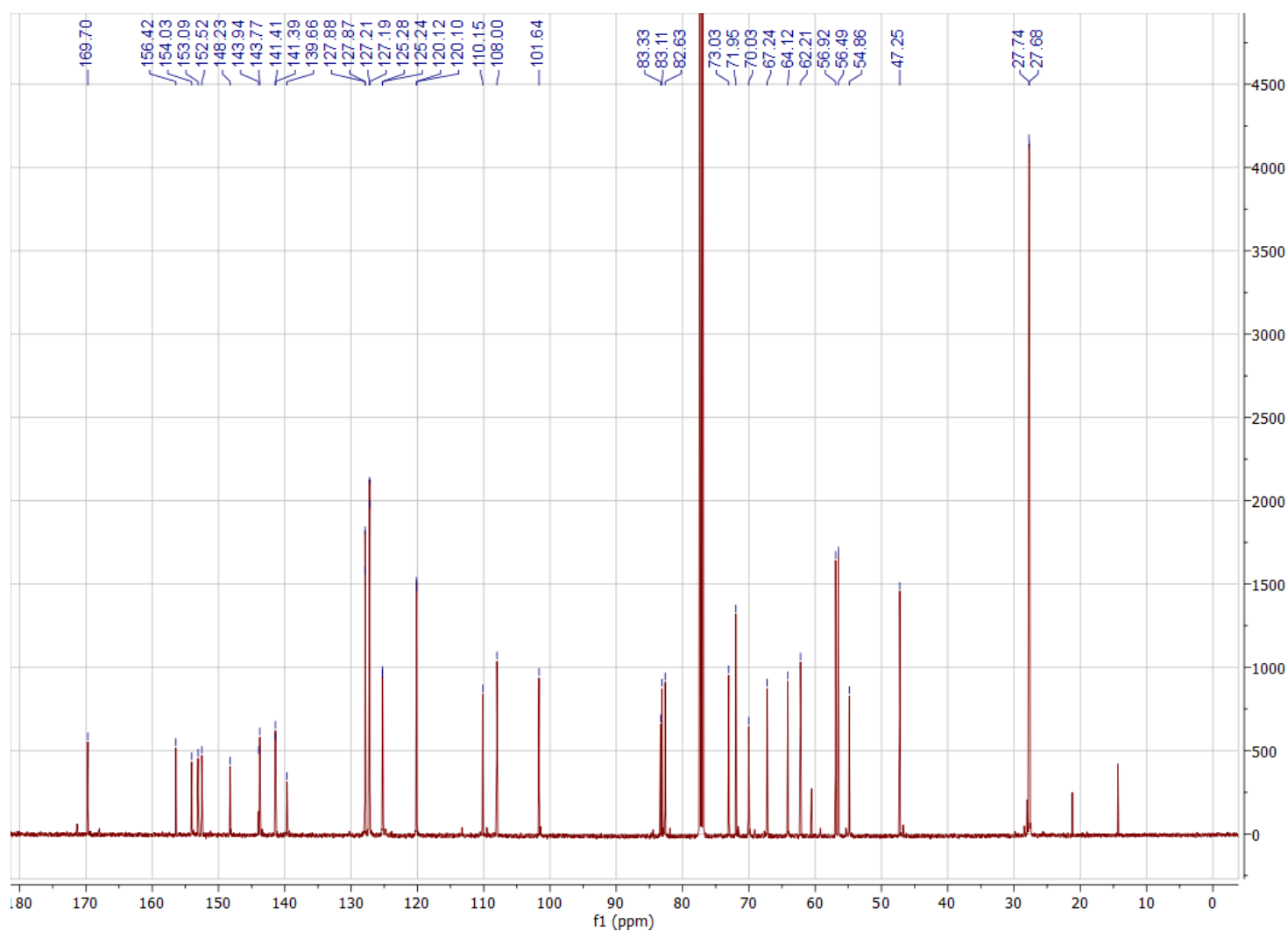




\section{Compound $1 \mathrm{~h}$}

\section{${ }^{1} \mathrm{H}$ NMR}

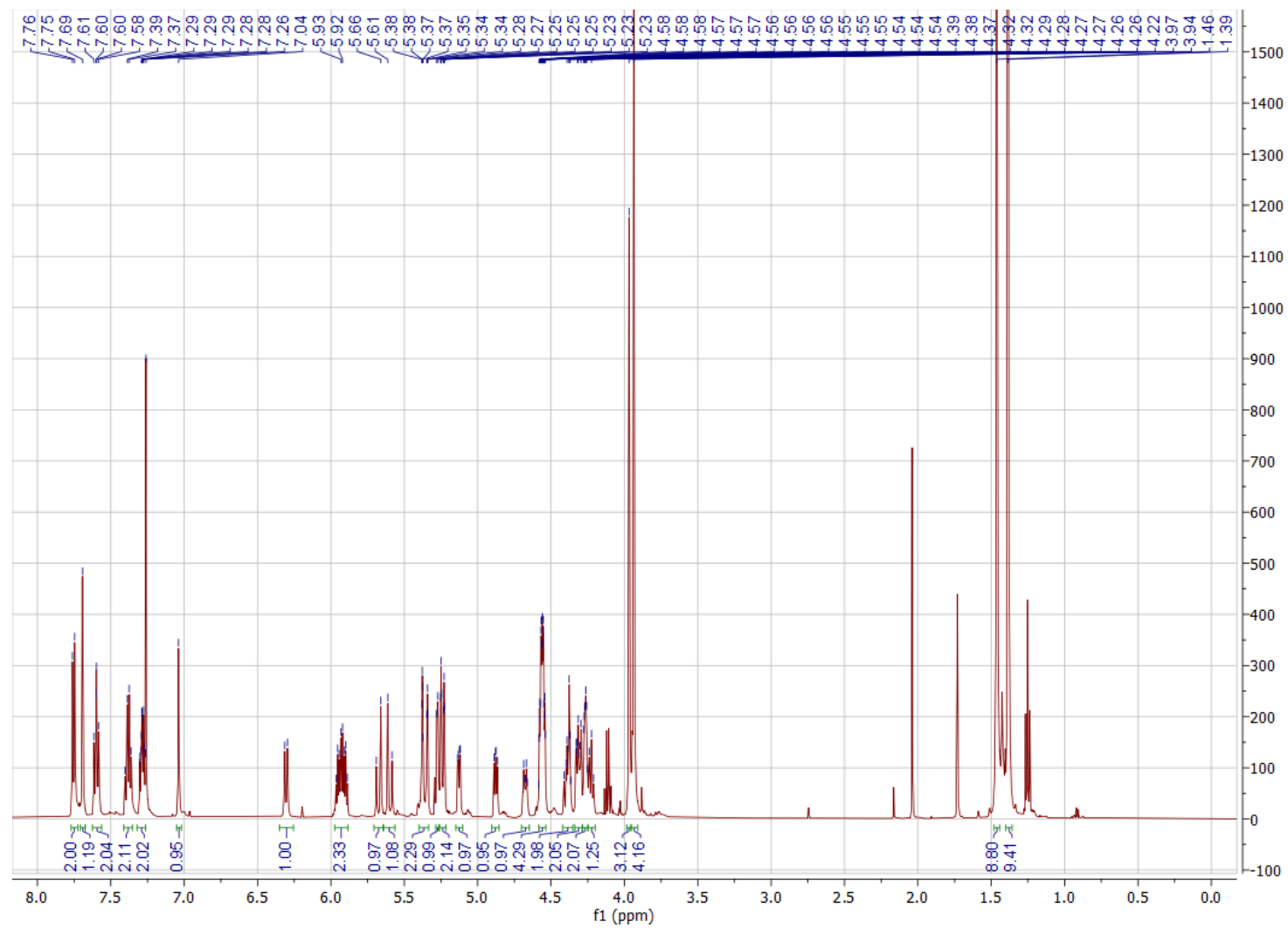

${ }^{13} \mathrm{C}$ NMR

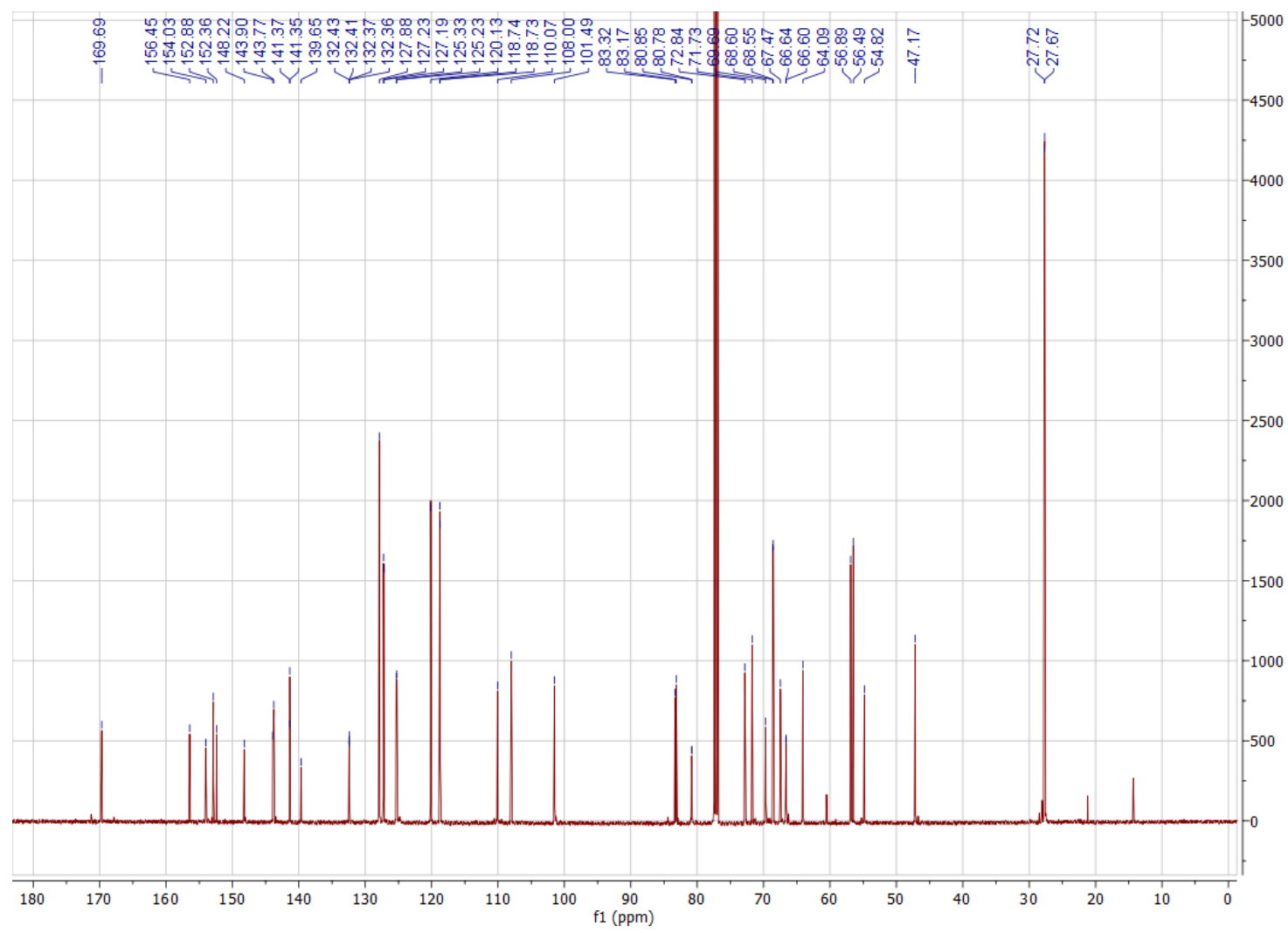




\section{Compound 1}

\section{${ }^{1} \mathrm{H}$ NMR}

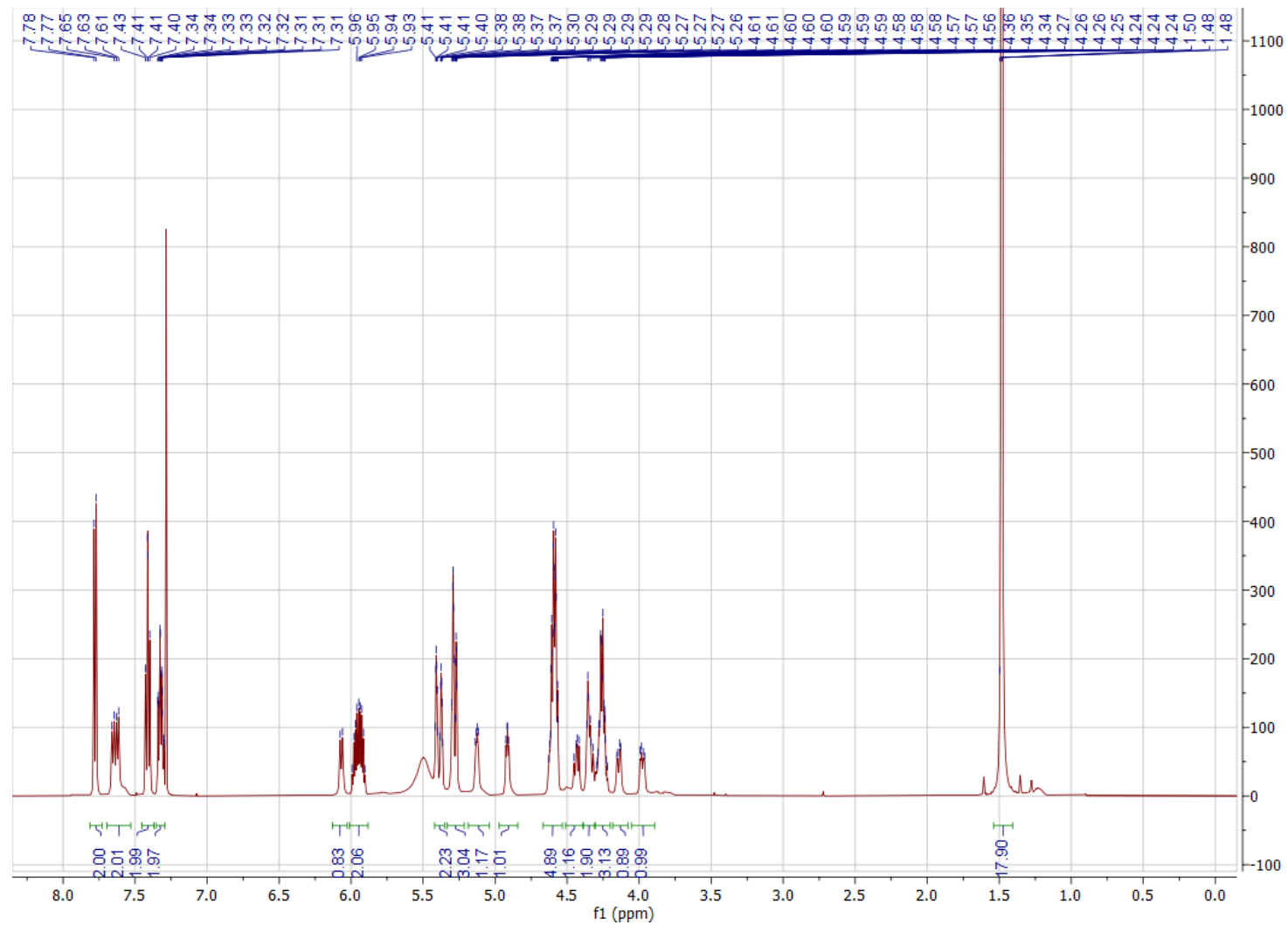

${ }^{13} \mathrm{C}$ NMR

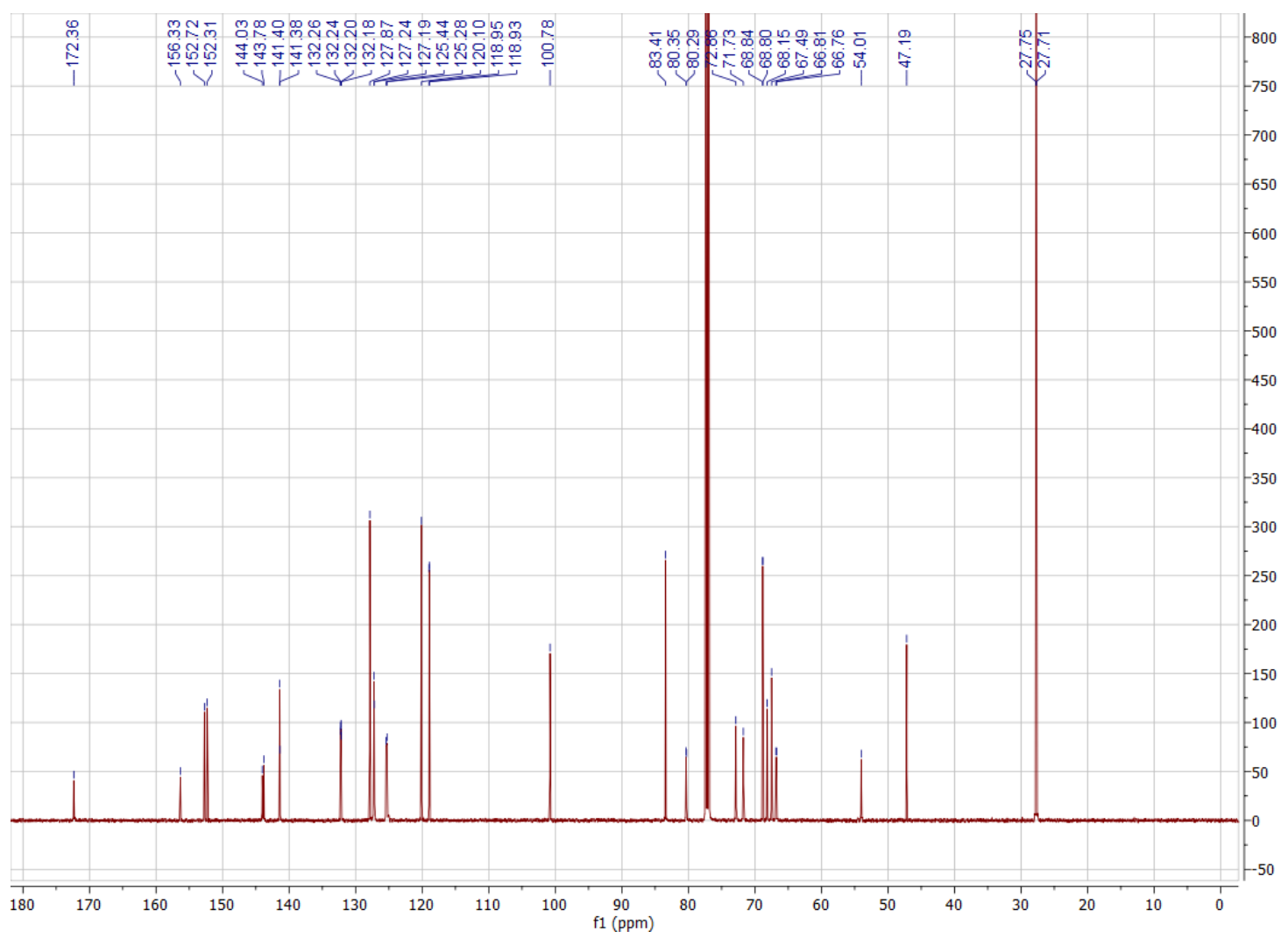




\section{Compound $\mathbf{2 b}$}

\section{${ }^{1} \mathrm{H} N M R$}

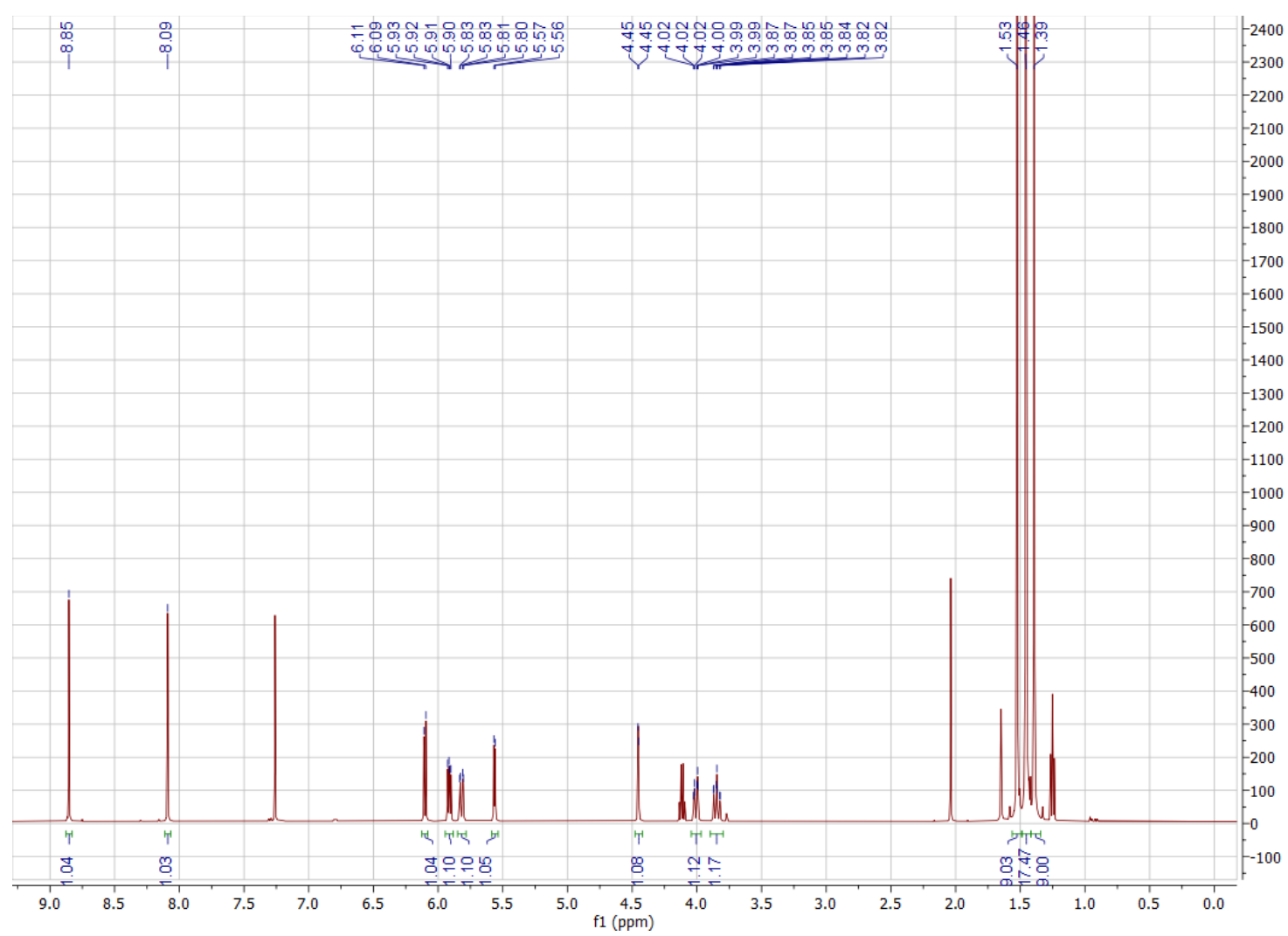

${ }^{13} \mathrm{C}$ NMR

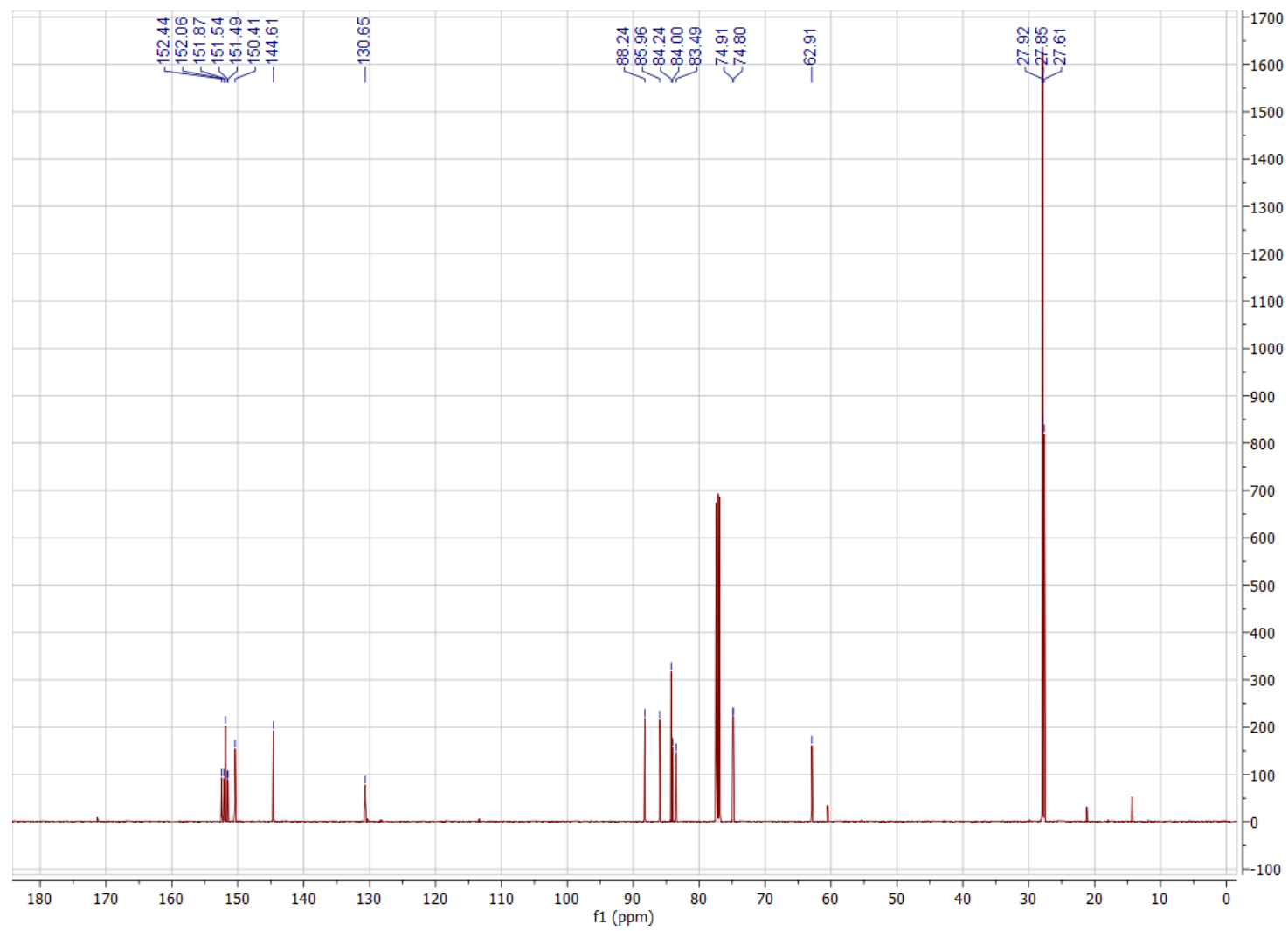




\section{Compound 2}

\section{${ }^{1} \mathrm{H}$ NMR}

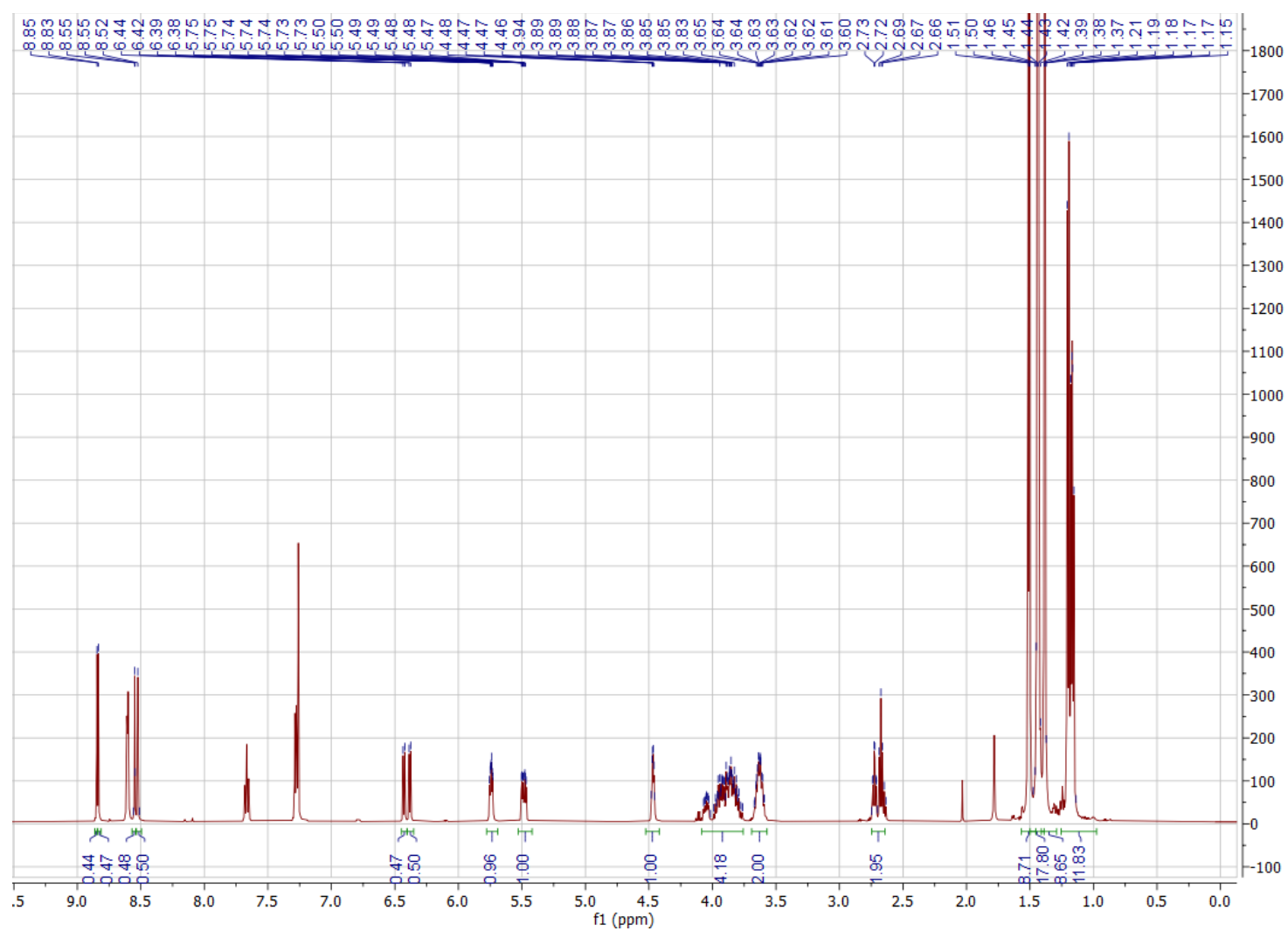

${ }^{13} \mathrm{C}$ NMR

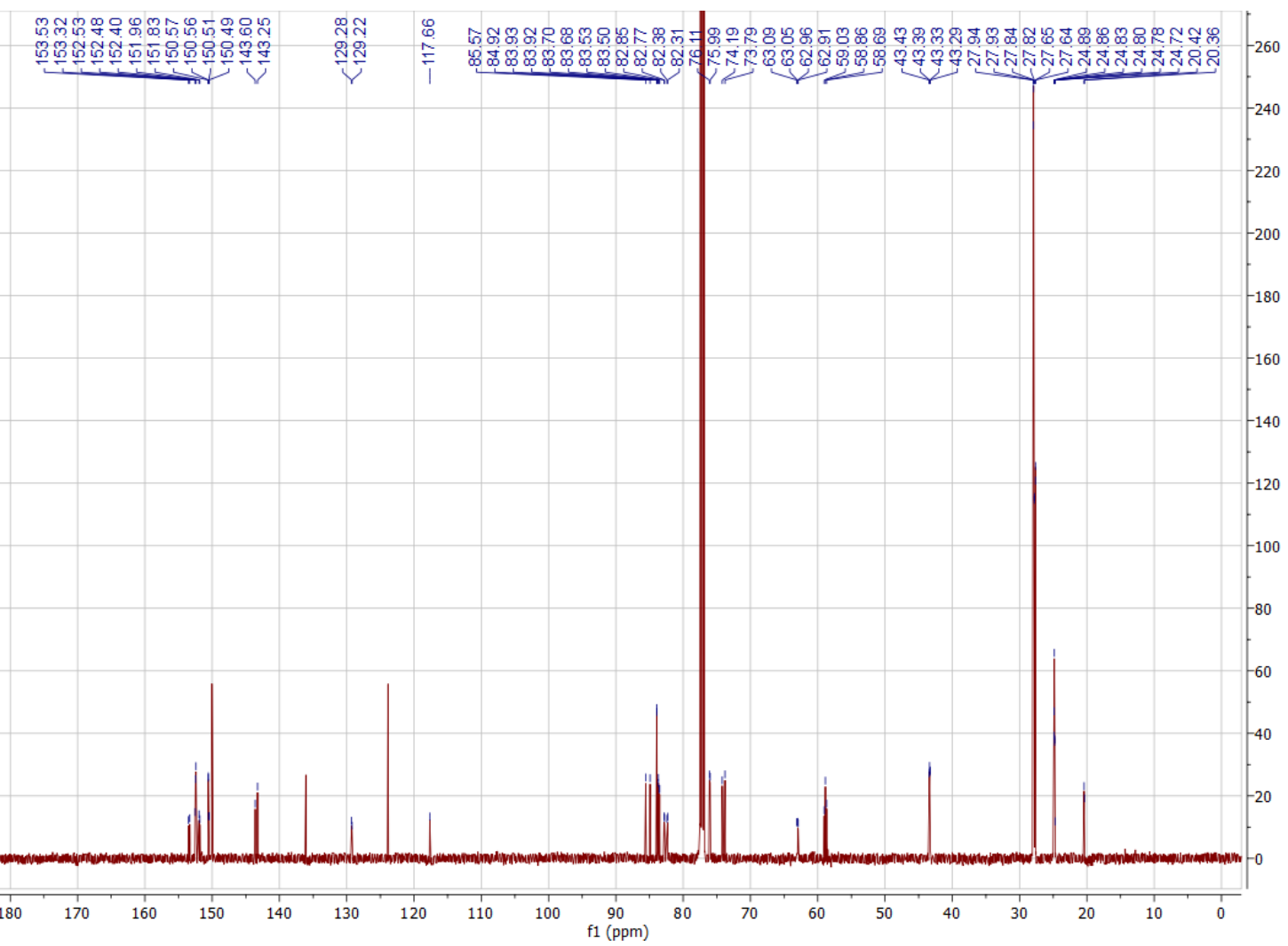


${ }^{31} \mathrm{P} N M R$

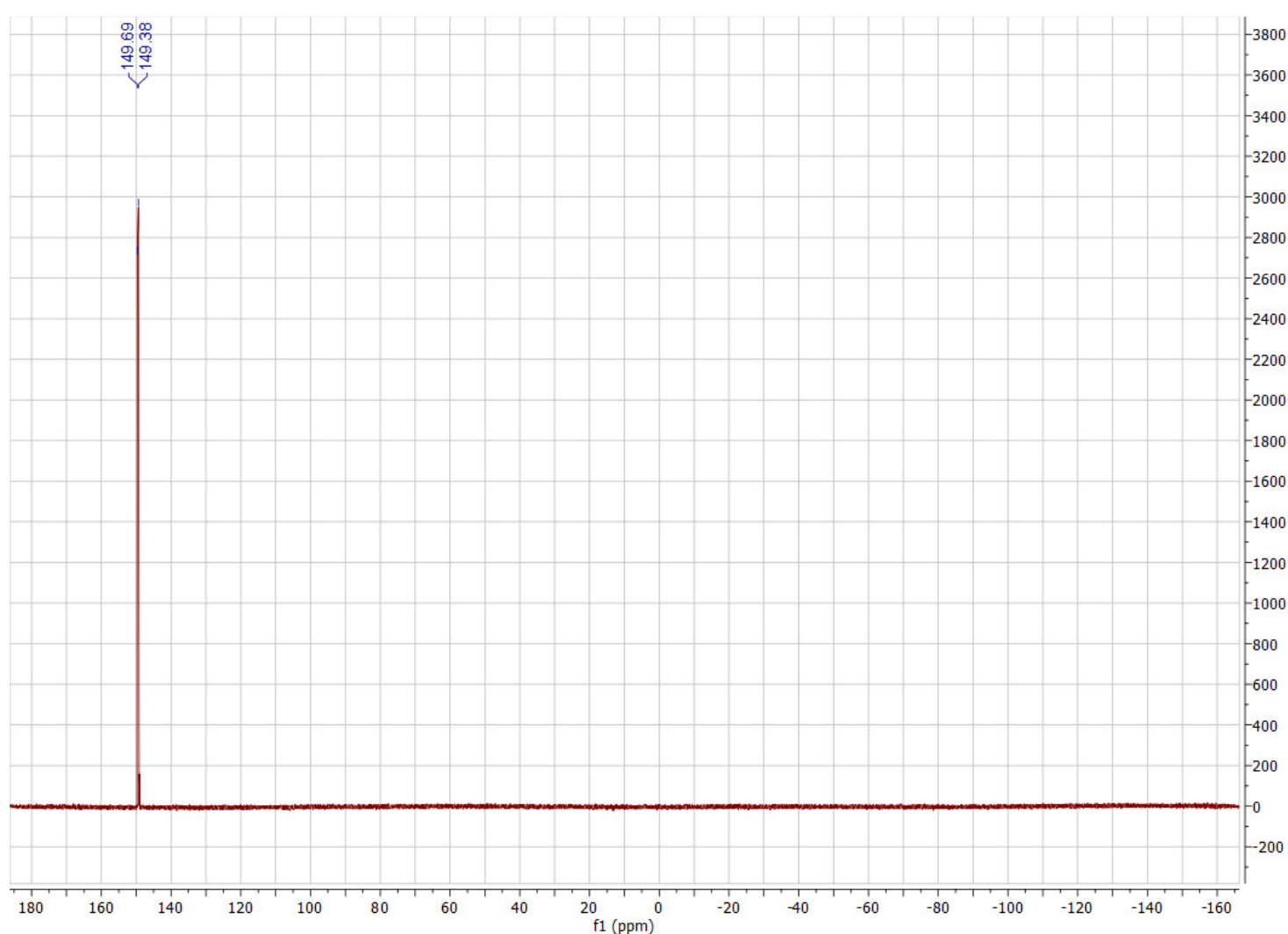




\section{References}

(1) Isidro, A.; Latassa, D.; Giraud, M.; Álvarez, M.; Albericio, F. 1,2-Dimethylindole-3-Sulfonyl (MIS) as Protecting Group for the Side Chain of Arginine. Org. Biomol. Chem. 2009, 7 (12), 2565-2569.

(2) Flood, D. T.; Hintzen, J. C. J.; Bird, M. J.; Cistrone, P. A.; Chen, J. S.; Dawson, P. E. Leveraging the Knorr Pyrazole Synthesis for the Facile Generation of Thioester Surrogates for Use in Native Chemical Ligation. Angew. Chem. Int. Ed. 2018, 57 (36), 11634-11639.

(3) Ge, E. J.; Jani, K. S.; Diehl, K. L.; Müller, M. M.; Muir, T. W. Nucleation and Propagation of Heterochromatin by the Histone Methyltransferase PRC2: Geometric Constraints and Impact of the Regulatory Subunit JARID2. J. Am. Chem. Soc. 2019, 141 (38), 15029-15039.

(4) Chiang, K. P.; Jensen, M. S.; McGinty, R. K.; Muir, T. W. A Semisynthetic Strategy to Generate Phosphorylated and Acetylated Histone H2B. ChemBioChem 2009, 10 (13), 2182-2187.

(5) Liszczak, G.; Diehl, K. L.; Dann, G. P.; Muir, T. W. Acetylation Blocks DNA Damage-Induced Chromatin ADP-Ribosylation. Nat. Chem. Biol. 2018, 14 (9), 837-840.

(6) Dyer, P. N.; Edayathumangalam, R. S.; White, C. L.; Bao, Y.; Chakravarthy, S.; Muthurajan, U. M.; Luger, K. B. T.-M. in E. Reconstitution of Nucleosome Core Particles from Recombinant Histones and DNA. In Methods in Enzymology; Academic Press, 2003; Vol. 375, pp 23-44.

(7) Lowary, P. T.; Widom, J. New DNA Sequence Rules for High Affinity Binding to Histone Octamer and Sequence-Directed Nucleosome Positioning. J. Mol. Biol. 1998, 276 (1), 19-42.

(8) Gibson, B. A.; Doolittle, L. K.; Schneider, M. W. G.; Jensen, L. E.; Gamarra, N.; Henry, L.; Gerlich, D. W.; Redding, S.; Rosen, M. K. Organization of Chromatin by Intrinsic and Regulated Phase Separation. Cell 2019, 179 (2), 470-484.e21.

(9) Taguchi, H.; Horikoshi, N.; Arimura, Y.; Kurumizaka, H. A Method for Evaluating Nucleosome Stability with a Protein-Binding Fluorescent Dye. Methods 2014, 70 (2), 119-126.

(10) Bagert, J. D.; Mitchener, M. M.; Patriotis, A. L.; Dul, B. E.; Wojcik, F.; Nacev, B. A.; Feng, L.; Allis, C. D.; Muir, T. W. Oncohistone Mutations Enhance Chromatin Remodeling and Alter Cell Fates. Nat. Chem. Biol. 2021, 17 (4), 403-411.

(11) Schuck, P. Size-Distribution Analysis of Macromolecules by Sedimentation Velocity Ultracentrifugation and Lamm Equation Modeling. Biophys. J. 2000, 78 (3), 1606-1619.

(12) van Holde-Weischet analysis http://www.analyticalultracentrifugation.com/sedfit_help_van_holde-weischet.htm.

(13) Dorigo, B.; Schalch, T.; Bystricky, K.; Richmond, T. J. Chromatin Fiber Folding: Requirement for the Histone H4 N-Terminal Tail. J. Mol. Biol. 2003, 327 (1), 85-96.

(14) Debelouchina, G. T.; Gerecht, K.; Muir, T. W. Ubiquitin Utilizes an Acidic Surface Patch to 
Alter Chromatin Structure. Nat. Chem. Biol. 2017, 13, 105.

(15) Patnaik, D.; Chin, H. G.; Estève, P.-O.; Benner, J.; Jacobsen, S. E.; Pradhan, S. Substrate Specificity and Kinetic Mechanism of Mammalian G9a Histone H3 Methyltransferase. J. Biol. Chem. 2004, 279 (51), 53248-53258.

(16) Zhao, S.; Chuh, K. N.; Zhang, B.; Dul, B. E.; Thompson, R. E.; Farrelly, L. A.; Liu, X.; Xu, N.; Xue, Y.; Roeder, R. G.; et al. Histone H3Q5 Serotonylation Stabilizes H3K4 Methylation and Potentiates Its Readout. Proc. Natl. Acad. Sci. 2021, 118 (6), e2016742118.

(17) Diehl, K. L.; Ge, E. J.; Weinberg, D. N.; Jani, K. S.; Allis, C. D.; Muir, T. W. PRC2 Engages a Bivalent H3K27M-H3K27me3 Dinucleosome Inhibitor. Proc. Natl. Acad. Sci. 2019, 116 (44), 22152 LP -22157.

(18) Wang, W.-B.; Huang, M.-H.; Li, Y.-X.; Rui, P.-X.; Hu, X.-G.; Zhang, W.; Su, J.-K.; Zhang, Z.-L.; Zhu, J.-S.; Xu, W.-H. A Practical Synthesis of Sugar-Derived Cyclic Nitrones: Powerful Synthons for the Synthesis of Iminosugars. Synlett 2010, 2010 (3), 488-492.

(19) Voorneveld, J.; Rack, J. G. M.; Ahel, I.; Overkleeft, H. S.; van der Marel, G. A.; Filippov, D. V. Synthetic $\alpha$ - and $\beta$-Ser-ADP-Ribosylated Peptides Reveal $\alpha$-Ser-ADPr as the Native Epimer. Org. Lett. 2018, 20 (13), 4140-4143. 